\title{
Association of TPH-1 and TPH-2 gene polymorphisms with suicidal behavior: a systematic review and meta-analysis
}

\author{
Thelma Beatriz González-Castro ${ }^{1}$, Isela Juárez-Rojop ${ }^{1}$, María Lilia López-Narváez²,3 and Carlos Alfonso Tovilla-Zárate ${ }^{4^{*}}$
}

\begin{abstract}
Background: It is widely acknowledged that suicidal behavior (SB) has a genetic influence. As a consequence, molecular genetic studies have been mostly conducted on serotonergic genes. One of the most promising candidate genes of this system is tryptophan hydroxylase (TPH). Although there have been several positive studies associating TPH genes and SB, the evidence is not entirely consistent. Therefore, we performed a meta-analysis to gain a better understanding into this issue.

Methods: The meta-analysis was conducted with 37 articles of genetic association studies of TPH-1 (A218C and A779C) and TPH2 (G-703 T, A-473 T and G19918A) genes. To analyze the association of these variants with SB we used the following models: allelic, additive, dominant and recessive. In addition, we performed a sub-group analysis by Caucasian and Asian populations using the same four models.

Results: TPH-1 gene variants showed a positive significant association with $\mathrm{SB}$, but only in the fixed effects models. With regard to $\mathrm{TPH}-2$ gene variants we could not find an association with SB.

Conclusions: The study provides evidence that A218C/A779C TPH-1 variants may be a risk factor to manifest SB at the clinical level, which is in agreement with previously reported meta-analyses. With regard to G-703 T/A-473 T/G19918A TPH-2 variants, our up-to-date meta-analysis could not detect any significant association between those genetic variants and SB. However, these results should be interpreted with caution since further studies need to be undertaken using larger sample sizes in different ethnic populations to confirm our findings.
\end{abstract}

Keywords: Suicidal behavior, Systematic review, Meta-analysis, TPH-1 gene, TPH-2 gene

\section{Background}

Suicidal behavior (SB) is a leading cause of injury and death worldwide; it accounts for almost one million deaths annually and is the leading cause of death among individuals between 15 and 44 years of age [1-3]. Suicide has been defined as the act of intentionally ending one's own life. Nonfatal suicidal thoughts and behaviors are classified more specifically into three categories: suicide ideation (refers to thoughts and plans for ending one's life), suicide attempt (engagement in potentially self-injurious behavior with no lethal outcome) and completed suicide (the person ends with his/her life). There are several

\footnotetext{
*Correspondence: alfonso_tovillaz@yahoo.com.mx

${ }^{4}$ División Multidisciplinaria de Comalcalco, Universidad Juárez Autónoma de Tabasco, Ranchería Sur, Cuarta Sección, C.P. 86650 Comalcalco, Tabasco, México

Full list of author information is available at the end of the article
}

measurements of past suicidal behavior, which basically consist in predicting future suicidal behavior, as well as to obtain information about history ideation, plans and/or attempts to commit suicide, among other data (e.g. DSM-IV diagnoses) [4-6].

A genetic influence in SB is now widely acknowledged and has received convincing support from familial, twin and adoption studies $[7,8]$, together with molecular genetic studies mostly conducted on serotonergic candidate genes. Moreover, the evidence from these various genetic studies indicates that dysfunctions of the central serotonergic system are involved in the pathogenesis of suicidal behavior [9]. In this manner, of the several serotonin-related genes studied in relation to $\mathrm{SB}$, one of the most promising is tryptophan hydroxylase (TPH) [10]. The principal reason for testing the association between TPH genes and SB 
is that TPH is the first and rate-limiting step in the synthesis of the serotonin neurotransmitter [11]. TPH genes have been associated with low CSF 5-HIAA levels in healthy volunteers and have been suggested as a quantitative risk factor, in which a greater effect of the gene results in the intensification of serotonergic dysfunction associated with higher levels of anger and more severe suicidal acts $[12,13]$.

With regard to the TPH enzyme there are two genes encoding it, both lie on intron seven: TPH-1, located on the human chromosome 11p15.3-14, has an approximate length of $29 \mathrm{~kb}$ and contains at least 11 exons and TPH-2 on chromosome 12q 21.1 covers a region of about $97 \mathrm{~kb}$ and comprises also 11 exons [14]. Thus, variations in TPH genes have prompted several researchers to conduct association genetic studies on TPH single-nucleotide polymorphisms (SNPs) [15]. Of the several different polymorphisms studied, most researches have focused on two SNPs in TPH1 [16]. The first polymorphism, A779C (rs1799913), was identified by single strand conformational analysis and comes mainly in two alternative forms or alleles TPH 779A and $\mathrm{TPH} 779 \mathrm{C}$, referred to as $\mathrm{U}$ and L, respectively [17]. The second polymorphism, A218C (rs1800532), is in complete or strong linkage disequilibrium with A779C in various populations; both have been studied somewhat interchangeably [9]. With regard to TPH2 gene variants, the association with suicidal behavior is in progress and until now several SNPs have been studied [10]. However, the most common SNPS studied in connection with SB are rs4570625 (G-703 T), rs11178997 (A-473 T) and rs1386494 (G19918A) [18]. These SNPs have been selected for their functional relevance. As a result, the G-703 $\mathrm{T}$ polymorphism has been reported in higher number in suicidal depressed patients compared with healthy controls, whereas the A-473 T polymorphism has raised large interest for its possible effect on gene expression in the brainstem of depressed patients who committed suicide [19]. Finally, the G19918A polymorphism has been found in association with completed suicides [20].

Although there have been several positive studies associating TPH genes and SB the evidence is inconsistent. These inconclusive results are probably due to small sample sizes, different polymorphic markers used in the analysis, as well as variations in sampling strategies, mainly in the control groups, and the different ethnic populations assessed [21]. Although there are previous meta-analyses [18,22-25], we decided to undertake another study in which in larger number sample size and more rigorous selection criteria could give us a better understanding into this matter. The aims of the present study were to analyze the association of TPH-1 (A218C and A779C) and TPH2 (G-703 T, A-473 T and G19918A) genes with SB using a meta-analysis and to integrate the outcomes of the several genetic studies included in this methodology by taking into account heterogeneity sources and the evaluation of possible bias in publication. Given that several authors have shown that the frequencies of TPH-1 and TPH-2 gene variants may be ethnic-dependent, we decided to perform a sub-group analysis by populations.

\section{PICOT question}

In population with suicidal behavior, what is the influence of TPH-1 and TPH2 genes variants in manifesting a clinical expression of suicidal behavior when compared to healthy subjects?

\section{Methods}

The research protocol of this analysis is available upon request. The meta-analysis and systematic review were performed by following the Preferred Reporting Items for Systematic Reviews and Meta-Analyses (PRISMA) criteria $[26,27]$.

\section{Identification and selection of publications}

Data were obtained by searching in EBSCO and PubMed databases from May to Jun 2013. Relevant publications were identified using the following search terms: "TPH1 and suicidal behavior" (PubMed: 23; EBSCO: 17), "TPH2 and suicidal behavior" (PubMed: 28; EBSCO: 29), "TPH1 and suicide" (PubMed: 25; EBSCO: 17), "TPH2 and suicide" (PubMed: 46; EBSCO: 39), "Tryptophan hydroxylase and suicidal behavior" (PubMed: 90; EBSCO: 53). These words were combined to retrieve the summaries. The search also implicated the review of the bibliography cited at the end of the various research articles. To be selected, the publications had to meet the following criteria: (1) to be published in peer-reviewed journals, (2) to contain independent data, (3) to be case-control association studies in which the frequencies of three genotypes were clearly stated or could be calculated, (4) diagnosis of suicidal behavior of the patients in the study (suicide ideation, suicide attempt and completed suicide), and (5) the use of healthy individuals as controls. A final requirement was that the articles were written in English. The following polymorphisms were studied: A779C (rs1799913) and A218C (rs1800532) of the TPH-1 gene, and rs4570625 (G-703 T), rs11178997 (A-473 T), and rs1386494 (G19918A) of the TPH-2 gene.

Two researchers (González-Castro and Juárez-Rojop) working independently screened each of the titles, abstracts, and full texts to determine inclusion. When the researchers were in disagreement a third researcher (Tovilla-Zárate) was consulted.

\section{Data extraction}

The same authors mentioned above carefully extracted the information from all the included publications. They worked in an independent manner and in accordance 


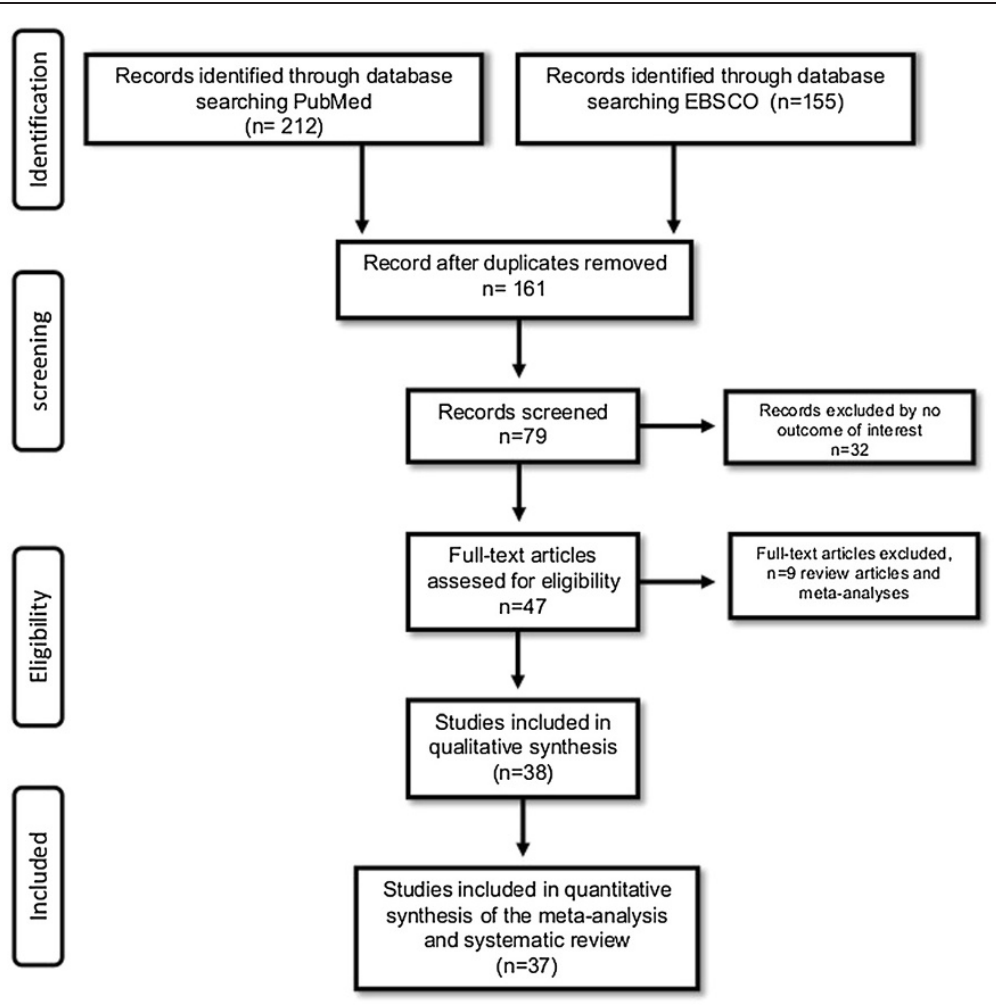

Figure 1 Flow-chart showing the search strategy and inclusion/exclusion criteria used in the meta-analysis and systematic review.

with the inclusion criteria listed above. The following data were obtained from each of the studies: authors, year of publication, region, number of cases and controls, age, gender, psychiatric diagnosis, number of males in the groups and ethnical origin of the participants. These data were not always available for all the studies. In the cases of missing data, we contacted the respective authors to ask for the allele frequencies not included in the main text of the papers. One of the studies did not include a control group [28], but we made an adjustment accordingly based

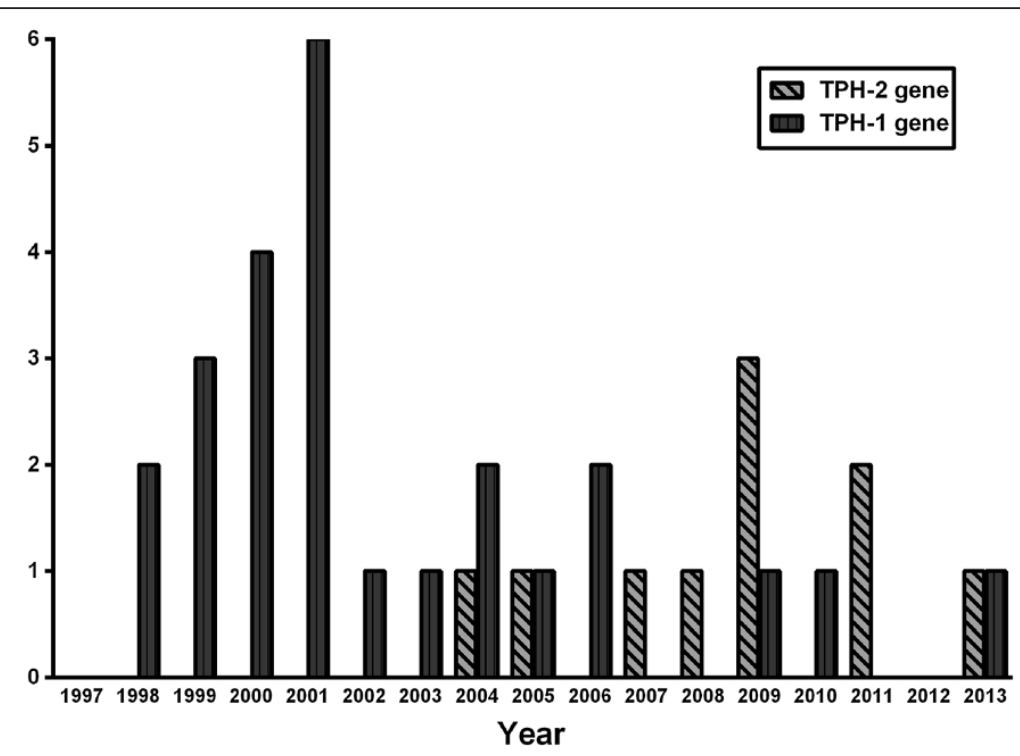

Figure 2 Distribution of association studies (cases-controls) on TPH genes variants and SB published in PubMed by year. 


\begin{tabular}{|c|c|c|c|c|c|c|c|c|c|c|c|c|}
\hline \multirow[t]{3}{*}{ Reference } & \multirow[t]{3}{*}{ Location } & \multirow[t]{3}{*}{ Diagnosis } & \multicolumn{2}{|c|}{ Number of males } & \multicolumn{2}{|c|}{ Number } & \multicolumn{2}{|c|}{ Genotypes } & \multicolumn{2}{|c|}{ Alleles } & \multicolumn{2}{|c|}{$P$ for HWE } \\
\hline & & & Cases & $\overline{\text { Controls }}$ & Cases & $\overline{\text { Controls }}$ & Cases & Controls & Cases & Controls & Cases & Control \\
\hline & & & & & & & $\mathrm{AA} / \mathrm{AC} / \mathrm{CC}$ & $\mathrm{AA} / \mathrm{AC} / \mathrm{CC}$ & $\mathrm{A} / \mathrm{C}$ & $\mathrm{A} / \mathrm{C}$ & & \\
\hline \multicolumn{13}{|c|}{ Caucasian population (A218C TPH-1 variant) } \\
\hline Bellivier F. et al., 1998 [62] & France & SA and manic-depression & - & 57 & 104 & 94 & $34 / 48 / 22$ & $11 / 45 / 38$ & $116 / 92$ & $67 / 121$ & 0.08 & 0.55 \\
\hline Geijer T. et al., 2000 [53] & Sweden & SA & 57 & 64 & 165 & 98 & $30 / 87 / 48$ & $13 / 47 / 38$ & $147 / 183$ & $73 / 123$ & 1.00 & 0.43 \\
\hline Du L. et al., 2000 [54] & Canada & SC & - & - & 35 & 84 & $6 / 24 / 5$ & 13/52/19 & $36 / 34$ & $78 / 90$ & $0.04^{*}$ & $0.04^{*}$ \\
\hline Souery D. et al., 2001 [37] & $\begin{array}{l}\text { Germany, Greece, Israel, } \\
\text { Italy, Sweden, UK. }\end{array}$ & SI and bipolar disorder & - & - & 167 & 167 & $29 / 85 / 53$ & $27 / 74 / 66$ & 143/191 & $128 / 206$ & 0.41 & 0.75 \\
\hline Abbar M. et al., 2001 [47] & France & SA & 105 & 170 & 231 & 281 & $43 / 120 / 68$ & $30 / 133 / 118$ & $206 / 256$ & $193 / 369$ & 0.50 & 0.30 \\
\hline Zalsman G.et al., 2001 [40] & Israel & SA & 40 & 74 & 84 & 172 & $16 / 34 / 34$ & $41 / 85 / 46$ & $66 / 102$ & $167 / 178$ & 0.89 & 0.17 \\
\hline Turecki G. et al., 2001 [39] & Canada & SC & - & - & 101 & 129 & $18 / 48 / 35$ & 18/71/40 & $84 / 118$ & 107/151 & 0.15 & 0.83 \\
\hline Rujescu D. et al., 2002 [36] & Germany & SA and anger related traits & 27 & 66 & 86 & 154 & $10 / 48 / 28$ & 19/78/57 & $68 / 104$ & $116 / 192$ & 0.39 & 0.17 \\
\hline Rujescu D. et al., 2003 [24] & Germany & SA & 52 & - & 147 & 326 & $18 / 81 / 48$ & 40/155/131 & $117 / 177$ & $235 / 417$ & 0.63 & 0.08 \\
\hline Jernej B. et al., 2004 [34] & Croatia & SC & 144 & 298 & 185 & 358 & $84 / 85 / 16$ & $202 / 141 / 15$ & $253 / 117$ & $545 / 171$ & 0.14 & 0.49 \\
\hline Stefulj J. et al., 2005 [16] & Croatia & SC & 160 & 284 & 160 & 284 & $21 / 69 / 70$ & $44 / 145 / 95$ & $111 / 209$ & $233 / 335$ & 0.39 & 0.60 \\
\hline Stefulj J. et al., 2006 [46] & Croatia & SC & 247 & 320 & 247 & 320 & $33 / 111 / 103$ & $50 / 162 / 108$ & $177 / 317$ & $262 / 378$ & 0.48 & 0.78 \\
\hline Viana M.M. et al., 2006 [48] & Brazil & $\begin{array}{l}\text { SA, major depression, } \\
\text { schizophrenia and } \\
\text { alcoholism }\end{array}$ & 142 & 36 & 248 & 63 & $45 / 125 / 78$ & $7 / 31 / 25$ & $215 / 281$ & $45 / 81$ & 0.78 & 0.79 \\
\hline Baud P. et al., 2009 [28] & Switzerland, France & SA & 166 & - & 537 & 1027 & $99 / 256 / 182$ & $181 / 483 / 363$ & $454 / 260$ & $845 / 1209$ & 0.59 & 0.34 \\
\hline Wilson T.et al., 2009 [52] & USA & SA and bipolar disorder & - & 39 & 71 & 101 & $13 / 44 / 14$ & $22 / 43 / 36$ & $70 / 72$ & $87 / 115$ & 0.22 & $0.05^{*}$ \\
\hline Saetre P. et al., 2010 [23] & $\begin{array}{l}\text { Denmark, Norway, } \\
\text { Sweden }\end{array}$ & SA and schizophrenia & - & 845 & 825 & 1460 & 289/391/145 & $570 / 694 / 196$ & $969 / 681$ & $1834 / 1086$ & $0.00^{*}$ & 0.63 \\
\hline \multirow[t]{2}{*}{ Buttenschon H.N. et al., 2013 [41] } & Denmark & SC & 209 & 763 & 490 & 1027 & $80 / 228 / 182$ & $181 / 843 / 363$ & $388 / 592$ & $845 / 1209$ & 0.36 & 0.57 \\
\hline & & & & & & & $868 / 1884 / 1131$ & $1469 / 3282 / 1754$ & & & 0.11 & 0.37 \\
\hline \multicolumn{13}{|c|}{ Asian population (A218C TPH-1 variant) } \\
\hline Tsai S.J. et al., 1999 [55] & Taiwan & SA and mood disorders & - & - & 41 & 200 & $17 / 15 / 9$ & $33 / 113 / 54$ & $49 / 33$ & $179 / 221$ & 0.06 & 0.19 \\
\hline Liu X. et al., 2006 [56] & China & SA & 171 & 98 & 287 & 177 & $72 / 148 / 67$ & $41 / 84 / 49$ & $292 / 282$ & $166 / 182$ & 0.65 & 0.63 \\
\hline Yoon H.K. et al., 2008 [44] & Korea & SA and major depression & 70 & 73 & 193 & 191 & $49 / 97 / 45$ & $60 / 85 / 48$ & 195/187 & 205/181 & 0.11 & 0.88 \\
\hline Kunugi H. et al.,1999 [42] & Japan & SA & - & 95 & 46 & 208 & $10 / 29 / 7$ & $55 / 105 / 48$ & $49 / 43$ & $215 / 201$ & 1.00 & 0.13 \\
\hline Paik I. et al., 2000 [45] & Korea & SA and schizophrenia & - & 124 & 27 & 236 & $04 / 12 / 11$ & $66 / 116 / 54$ & $20 / 34$ & $248 / 224$ & 0.89 & 1.00 \\
\hline Ono H., et al., 2000 [43] & Japan & SC & 90 & 90 & 132 & 132 & $29 / 68 / 35$ & $26 / 71 / 35$ & $126 / 138$ & $123 / 141$ & 0.38 & 0.86 \\
\hline Hong C.J. et al., 2001 [35] & Taiwan & SA and schizophrenia & - & 123 & 140 & 251 & $42 / 57 / 41$ & $42 / 135 / 74$ & $141 / 139$ & $219 / 283$ & 0.15 & $0.02^{*}$ \\
\hline
\end{tabular}


Table 1 Descriptive characteristics in association studies on A218C/A779C TPH-1 gene variants and SB by populations (Continued)

\begin{tabular}{|c|c|c|c|c|c|c|c|c|c|c|c|c|}
\hline \multirow[t]{2}{*}{ Ohtani M. et al., 2004 [49] } & Japan & SC & 95 & 171 & 134 & 325 & $30 / 60 / 42$ & $44 / 113 / 57$ & $120 / 144$ & $201 / 227$ & 0.41 & 0.37 \\
\hline & & & & & & & $253 / 486 / 257$ & $367 / 822 / 419$ & & & & \\
\hline \multicolumn{13}{|c|}{ Caucasian population (A779C TPH-1 variant) } \\
\hline Nielsen D.A. et al.,1998 [38] & USA & SI and alcoholism & - & 232 & 102 & 232 & $17 / 57 / 28$ & $49 / 106 / 77$ & $91 / 113$ & $204 / 260$ & 0.28 & 0.23 \\
\hline Rotondo A. et al., 1999 [51] & Italy and USA & SA & - & 153 & 97 & 153 & $12 / 50 / 35$ & $33 / 68 / 52$ & $74 / 120$ & $215 / 201$ & 0.25 & 0.51 \\
\hline Roy A. et al., 2001 [17] & Sweden & SC & - & - & 24 & 158 & $02 / 12 / 20$ & $35 / 86 / 37$ & $16 / 332$ & $156 / 160$ & 0.33 & 1.00 \\
\hline Saetre P. et al., 2010 [23] & $\begin{array}{l}\text { Denmark, Norway and } \\
\text { Sweden }\end{array}$ & SA and schizophrenia & - & 845 & 830 & 1464 & 290/391/149 & $570 / 691 / 203$ & $971 / 689$ & $1831 / 1097$ & $0.00^{*}$ & 0.63 \\
\hline \multirow[t]{2}{*}{ Pooley E.C. et al., 2003 [50] } & UK & SA & 52 & 138 & 129 & 329 & $20 / 67 / 42$ & $44 / 135 / 150$ & $107 / 151$ & $223 / 435$ & 0.13 & 0.47 \\
\hline & & & & & & & $341 / 577 / 274$ & $731 / 1086 / 519$ & & & 0.44 & 0.34 \\
\hline \multicolumn{13}{|c|}{ Asian population (A779C TPH-1 variant) } \\
\hline Kunugi H. et al., 1999 [42] & Japan & SA & - & 95 & 46 & 208 & 10/29/7 & $55 / 105 / 48$ & $49 / 43$ & $215 / 201$ & 1.00 & 0.13 \\
\hline Ohtani M. et al., 2004 [49] & Japan & SC & 95 & 171 & 134 & 325 & $30 / 59 / 42$ & $45 / 138 / 82$ & $119 / 143$ & $228 / 302$ & 0.38 & 0.29 \\
\hline \multirow[t]{2}{*}{ Liu X., et al. 2006 [56] } & China & SA & 171 & 98 & 266 & 164 & $77 / 126 / 63$ & $43 / 85 / 36$ & $280 / 252$ & $171 / 157$ & 0.75 & 0.46 \\
\hline & & & & & & & $117 / 214 / 112$ & 143/328/166 & & & 0.50 & 0.47 \\
\hline
\end{tabular}


Table 2 Descriptive characteristics in association studies on G-703 T/A473T/G19918A TPH-2 gene variants and SB by populations

\begin{tabular}{|c|c|c|c|c|c|c|c|c|c|c|c|c|}
\hline \multirow[t]{3}{*}{ Reference } & \multirow[t]{3}{*}{ Location } & \multirow[t]{3}{*}{ Diagnosis } & \multicolumn{2}{|c|}{ Number of males } & \multicolumn{2}{|c|}{ Number } & \multicolumn{2}{|c|}{ Genotypes } & \multicolumn{2}{|c|}{ Alleles } & \multicolumn{2}{|c|}{ P for HWE } \\
\hline & & & Cases & Controls & Cases & Controls & Cases & Controls & Cases & Controls & Cases & Controls \\
\hline & & & & & & & $\mathrm{GG} / \mathrm{TG} / \mathrm{TT}$ & $\mathrm{GG} / \mathrm{TG} / \mathrm{TT}$ & T/G & $T / G$ & & \\
\hline \multicolumn{13}{|c|}{ Caucasian population (G-703 T TPH-2 variant) } \\
\hline Zhou Z. et al., 2005 [61] & USA & SA and major depression & 150 & 196 & 150 & 196 & $106 / 40 / 4$ & $132 / 58 / 6$ & $252 / 48$ & $322 / 70$ & 1.00 & 1.00 \\
\hline Zill P. et al., 2007 [60] & Germany & SA and alcoholism & - & 164 & 102 & 305 & $61 / 36 / 5$ & $191 / 101 / 13$ & $158 / 46$ & $483 / 127$ & 1.00 & 1.00 \\
\hline \multirow[t]{2}{*}{ Stefulj J. et al., 2011 [57] } & Croatia & SC & 291 & 280 & 291 & 280 & $181 / 96 / 14$ & 183/80/17 & $458 / 124$ & $446 / 114$ & 0.06 & 0.72 \\
\hline & & & & & & & $348 / 172 / 23$ & $506 / 239 / 36$ & & & 0.78 & 0.26 \\
\hline \multicolumn{13}{|c|}{ Asian population (G-703 T TPH-2 variant) } \\
\hline Mouri K. et al., 2009 [58] & Japan & SC & 156 & 162 & 234 & 260 & $62 / 117 / 55$ & $80 / 128 / 52$ & $241 / 227$ & $288 / 232$ & 1.00 & 1.00 \\
\hline \multirow[t]{2}{*}{ Yoon H.K. et al., 2008 [44] } & Korea & SA and major depression & 82 & 80 & 181 & 176 & $58 / 81 / 42$ & $34 / 82 / 60$ & $197 / 165$ & $150 / 202$ & 0.18 & 0.53 \\
\hline & & & & & & & 120/198/97 & $114 / 210 / 112$ & & & 0.37 & 0.44 \\
\hline \multirow[t]{3}{*}{ Reference } & Location & Diagnosis & \multicolumn{2}{|c|}{ Number of males } & \multicolumn{2}{|c|}{ Number } & \multicolumn{2}{|c|}{ Genotypes } & \multicolumn{2}{|c|}{ Alleles } & \multicolumn{2}{|c|}{$P$ for HWE } \\
\hline & & & Cases & Cases & Cases & Controls & Cases & Controls & Cases & Controls & Cases & Controls \\
\hline & & & & & & & $\mathrm{AA} / \mathrm{AT} / \mathrm{TT}$ & $\mathrm{AA} / \mathrm{AT} / \mathrm{TT}$ & $A / T$ & $A / T$ & & \\
\hline \multicolumn{13}{|c|}{ Caucasian population (A-473 TTPH-2 variant) } \\
\hline Zhou Z. et al., 2005 [61] & USA & SA and major depression & 150 & 196 & 150 & 196 & 0/14/136 & 0/15/181 & $14 / 286$ & $15 / 377$ & 1.00 & 1.00 \\
\hline \multirow[t]{2}{*}{ Zupanc T.et al., 2011 [19] } & Slovenia & SC and alcoholism & - & - & 383 & 222 & $0 / 42 / 341$ & 2/31/189 & $42 / 724$ & $35 / 409$ & 0.61 & 0.63 \\
\hline & & & & & & & $0 / 56 / 177$ & $2 / 46 / 370$ & & & 0.36 & 0.65 \\
\hline \multicolumn{13}{|c|}{ Asian population (A-473 T TPH-2 variant) } \\
\hline Mouri K.et al., 2009 [58] & Japan & SC & 156 & 162 & 234 & 260 & 2/44/188 & $3 / 48 / 209$ & $48 / 420$ & $54 / 466$ & 1.00 & 0.74 \\
\hline \multirow[t]{3}{*}{ Reference } & \multirow[t]{3}{*}{ Location } & \multirow[t]{3}{*}{ Diagnosis } & \multicolumn{2}{|c|}{ Number of males } & \multicolumn{2}{|c|}{ Number } & \multicolumn{2}{|c|}{ Genotypes } & & eles & $P$ fo & HWE \\
\hline & & & Cases & Cases & Cases & Controls & Cases & Controls & Cases & Controls & Cases & Controls \\
\hline & & & & & & & GG/GA/AA & GG/GA/AA & $\mathrm{G} / \mathrm{A}$ & $\mathrm{G} / \mathrm{A}$ & & \\
\hline Caucasian population ( G19918 & $T P H-2$ varic & & & & & & & & & & & \\
\hline Zill P. et al.,2004 [20] & Germany & SC & 191 & 138 & 263 & 266 & $195 / 63 / 5$ & $166 / 88 / 12$ & $453 / 73$ & $420 / 112$ & 1.00 & 1.00 \\
\hline Zill P. et al.,2007 [60] & Germany & SA and alcoholism & - & 164 & 102 & 305 & $4 / 31 / 67$ & $12 / 98 / 195$ & $39 / 165$ & $122 / 488$ & 0.75 & 1.00 \\
\hline Must A. et al., 2009 [59] & Estonia & SC & 298 & 327 & 288 & 327 & $206 / 75 / 7$ & $242 / 79 / 6$ & $487 / 89$ & $563 / 91$ & 1.00 & 1.00 \\
\hline Buttenschon H.N. et al.,2013 [41] & Denmark & SC & 209 & 763 & 553 & 1033 & $396 / 150 / 7$ & $743 / 268 / 22$ & $942 / 169$ & $1754 / 312$ & 0.09 & 0.08 \\
\hline & & & & & & & $801 / 319 / 86$ & $1163 / 533 / 235$ & & & 0.06 & 0.09 \\
\hline Asian population ( G19918A TPF & 2 variant) & & & & & & & & & & & \\
\hline K. Mouri et al.2009 [58] & Japan & SC & 156 & 162 & 234 & 260 & 219/15/0 & $239 / 21 / 0$ & $453 / 234$ & $499 / 260$ & 1.00 & 1.00 \\
\hline
\end{tabular}

$\mathrm{SA}=$ Suicide attempt $\mathrm{SI}=$ Suicide ideation, and $\mathrm{SC}=$ Suicide completion 
Table 3 Meta-analysis of case-control studies on A218C/A779C TPH-1 gene variants in patients with suicidal behavior

\begin{tabular}{|c|c|c|c|c|c|c|c|c|c|}
\hline \multicolumn{2}{|c|}{ Model analysis } & \multicolumn{2}{|c|}{ A218C } & \multirow{2}{*}{$\begin{array}{l}P \text { value } \\
\text { of } Q \text { test }\end{array}$} & \multirow{2}{*}{$\begin{array}{l}\text { P value of } \\
\text { Egger's test }\end{array}$} & \multicolumn{2}{|c|}{ A779C } & \multirow{2}{*}{$\begin{array}{l}P \text { value } \\
\text { of } Q \text { test }\end{array}$} & \multirow{2}{*}{$\begin{array}{l}P \text { value of } \\
\text { Egger's test }\end{array}$} \\
\hline & & $\begin{array}{l}\text { Random effects } \\
\text { OR (CI 95\%) }\end{array}$ & $\begin{array}{l}\text { Fixed effects } \\
\text { OR (Cl 95\%) }\end{array}$ & & & $\begin{array}{l}\text { Random effects } \\
\text { OR (Cl 95\%) }\end{array}$ & $\begin{array}{l}\text { Fixed effects } \\
\text { OR (Cl 95\%) }\end{array}$ & & \\
\hline \multicolumn{10}{|c|}{ All populations } \\
\hline \multirow[t]{2}{*}{ Allelic } & With heterogeneity & $1.10(0.98-1.22)$ & $1.09(1.04-1.16)$ & $<0.001$ & 0.85 & $0.96(0.76-1.22)$ & $1.09(0.99-1.21)$ & $<0.0001$ & 0.46 \\
\hline & Without heterogeneity & $1.02(0.94-1.11)$ & $1.01(0.95-1.08)$ & 0.11 & 0.27 & $0.97(0.85-1.11)$ & $0.97(0.85-1.11)$ & 0.43 & 0.24 \\
\hline \multirow[t]{2}{*}{ Additive } & With heterogeneity & $1.22(0.98-1.52)$ & $1.22(1.09-1.37)$ & $<0.00001$ & 0.95 & $1.02(0.67-1.54)$ & $1.29(1.04-1.59)$ & 0.001 & 0.25 \\
\hline & Without heterogeneity & $1.06(0.90-1.24)$ & $1.04(0.92-1.19)$ & 0.15 & 0.50 & $0.92(0.71-1.19)$ & $0.92(0.71-1.19)$ & 0.42 & 0.11 \\
\hline \multirow[t]{2}{*}{ Dominant } & With heterogeneity & $1.16(0.96-1.41)$ & $1.16(1.07-1.27)$ & $<0.0001$ & 0.93 & $1.17(0.75-1.83)$ & $1.43(1.21-1.69)$ & $<0.0001$ & 0.07 \\
\hline & Without heterogeneity & $1.04(0.91-1.18)$ & $1.02(0.93-1.13)$ & 0.07 & 0.65 & $1.00(0.82-1.22)$ & $1.00(0.82-1.22)$ & 0.47 & 0.73 \\
\hline \multirow[t]{2}{*}{ Recessive } & With heterogeneity & $1.10(0.94-1.28)$ & $1.04(0.95-1.15)$ & 0.0005 & 0.15 & & & & \\
\hline & Without heterogeneity & $0.97(0.87-1.08)$ & $0.97(0.87-1.08)$ & 0.97 & 0.80 & $0.88(0.72-1.08)$ & $0.90(0.76-1.06)$ & 0.23 & 0.23 \\
\hline \multicolumn{10}{|c|}{ Caucasian population } \\
\hline \multirow[t]{2}{*}{ Allelic } & With heterogeneity & $1.12(0.971 .29)$ & $1.10(1.04-1.17)$ & $<0.0001$ & 0.69 & $0.90(0.62-1.30)$ & $1.11(0.981 .25)$ & $<0.0001$ & 0.60 \\
\hline & Without heterogeneity & $1.01(0.91-1.13)$ & $1.00(0.93-1.08)$ & 0.006 & 0.36 & $0.95(0.78-1.14)$ & 0.95(0.78 1.14) & 0.58 & 0.25 \\
\hline \multirow[t]{2}{*}{ Additive } & With heterogeneity & $1.25(0.95-1.64)$ & $1.22(1.07-1.39)$ & $<0.0001$ & 0.73 & $0.89(0.46-1.71)$ & $1.36(1.051 .75)$ & $<0.0001$ & 0.80 \\
\hline & Without heterogeneity & $1.05(0.87-1.27)$ & $1.03(0.88-1.19)$ & 0.18 & 0.22 & $0.80(0.55-1.16)$ & $0.80(0.55-1.16)$ & 0.69 & 0.94 \\
\hline \multirow[t]{2}{*}{ Dominant } & With heterogeneity & $1.24(0.96-1.59)$ & $1.20(1.09-1.32)$ & $<0.0001$ & 0.68 & $1.17(0.75-1.83)$ & $1.43(1.21-1.69)$ & $<0.0001$ & 0.40 \\
\hline & Without heterogeneity & $1.12(0.97-1.28)$ & $1.10(0.97-1.25)$ & 0.35 & 0.06 & $1.09(0.83-1.44)$ & $1.09(0.83-1.44)$ & 0.77 & 0.58 \\
\hline \multirow[t]{2}{*}{ Recessive } & With heterogeneity & $1.02(0.841 .24)$ & $0.97(0.87-1.09)$ & $<0.0001$ & 0.34 & $0.81(0.67-0.98)$ & $0.81(0.670 .98)$ & $<0.0001$ & 0.30 \\
\hline & Without heterogeneity & $0.95(0.84-1.06)$ & $0.95(0.84-1.06)$ & 0.66 & 0.20 & $0.68(0.51-0.91)$ & $68(0.51-0.91)$ & 0.71 & 0.31 \\
\hline \multicolumn{10}{|c|}{ Asian population } \\
\hline \multirow[t]{2}{*}{ Allelic } & With heterogeneity & $1.06(0.89-1.27)$ & $1.06(0.94-1.20)$ & 0.04 & 0.72 & $1.05(0.881 .27)$ & $1.05(0.88-1.27)$ & 0.93 & 0.84 \\
\hline & Without heterogeneity & $1.11(0.95-1.28)$ & $1.10(0.971 .24)$ & 0.21 & 0.30 & & & & \\
\hline \multirow[t]{2}{*}{ Additive } & With heterogeneity & & & & & & & & \\
\hline & Without heterogeneity & $1.17(0.83-1.65)$ & $1.18(0.931 .50)$ & 0.06 & 0.69 & $1.15(0.79-1.68)$ & $1.15(0.79-1.68)$ & 0.83 & 0.76 \\
\hline \multirow[t]{2}{*}{ Dominant } & With heterogeneity & & & & & $0.99(0.73-1.35)$ & $0.99(0.73-1.35)$ & 0.45 & 0.10 \\
\hline & Without heterogeneity & $1.01(0.82-1.25)$ & $1.01(0.84-1.23)$ & 0.31 & 0.27 & $0.92(0.67 .1 .28)$ & $0.92(0.67-1.28)$ & 0.88 & 1.000 \\
\hline \multirow[t]{2}{*}{ Recessive } & With heterogeneity & $1.18(0.81-1.72)$ & $1.19(0.97-1.45)$ & 0.002 & 0.89 & $1.16(0.86-1.58)$ & $1.16(0.86-1.58)$ & 0.40 & 0.54 \\
\hline & Without heterogeneity & 0.94(0.74-1.18) & $0.94(0.74-1.18)$ & 0.52 & 0.27 & & & & \\
\hline
\end{tabular}


on the other studies in the literature that included a control group [29]. Briefly, we calculated the weighted frequency for a particular genotype from studies that included controls and applied it to the study without a control group. We considered the number of the "virtual" control group equal to the number of patients in the specific study. Then the hypothetical number of subjects with the particular genotype frequency was assigned in proportion to the

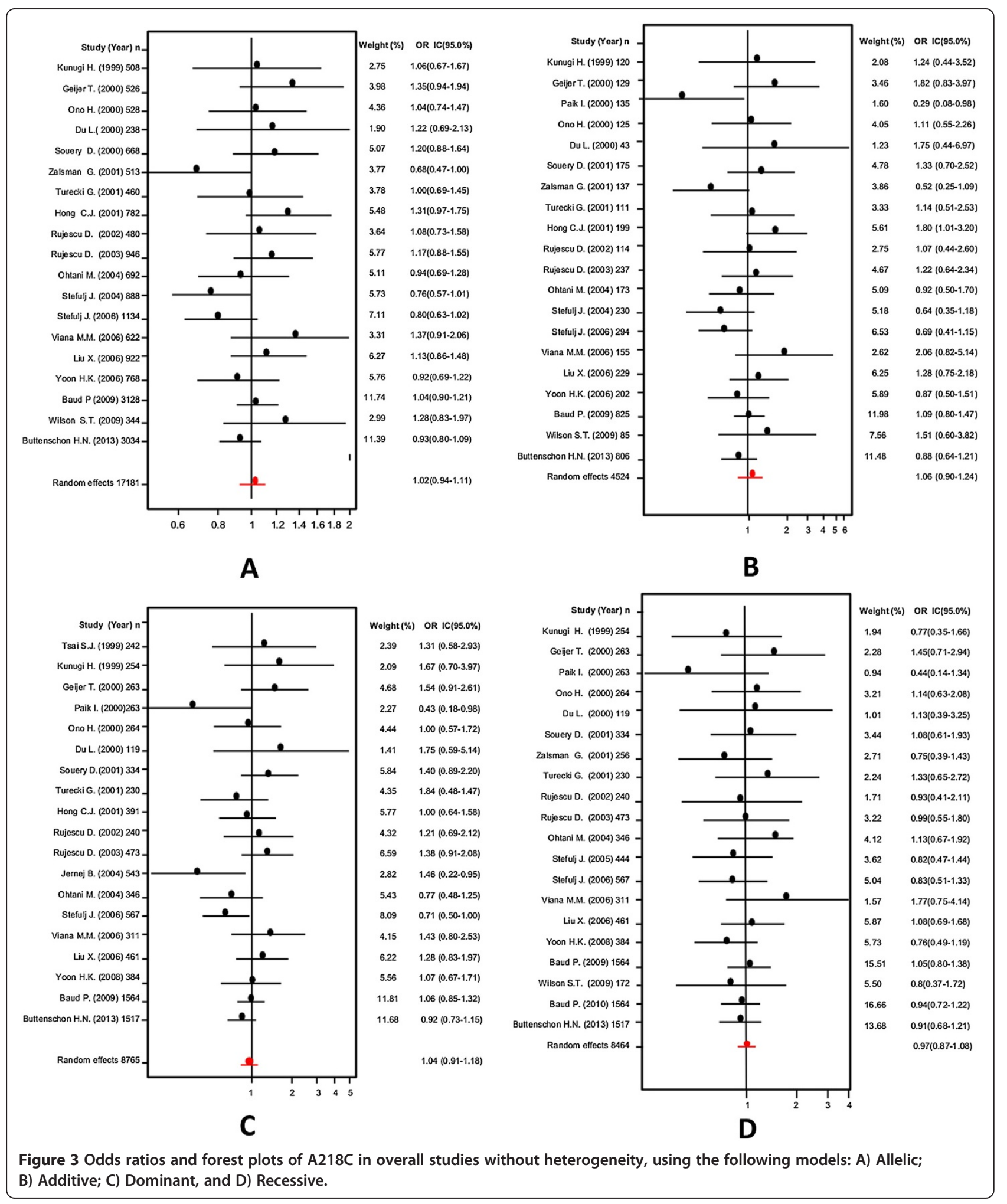


percentage of the same genotype which was obtained from the weighted analysis $[30,31]$. The outcomes of the metaanalysis were built by taking into consideration the categories reported in previously published studies $[32,33]$.

Figure 1 shows the stages of the meta-analysis. The combined search included 367 potentially relevant articles. Finally, 37 articles were obtained after discarding overlapping references that did not agree with the inclusion criteria [16,17,19-24,28,34-61]; Figure 2 shows the articles published at this stage of the analysis. In the case of
TPH-1 gene variants (A218C and A779C), 5683 cases and 11652 controls were involved, whereas for the TPH-2 gene variants (G-703 T, A-473 T and G19918A) 4196 cases and 5990 controls were considered (Tables 1 and 2, respectively).

\section{Data analysis}

For the meta-analysis procedures we used the EPIDAT 3.1 program (http://www.sergas.es/MostrarContidos_N3_T01. aspx?IdPaxina $=62715$ ). This software is freely available for

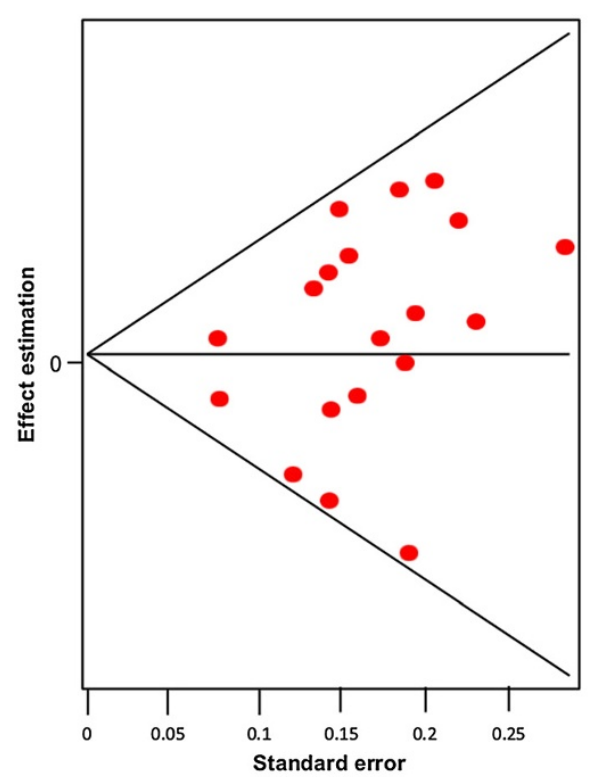

A

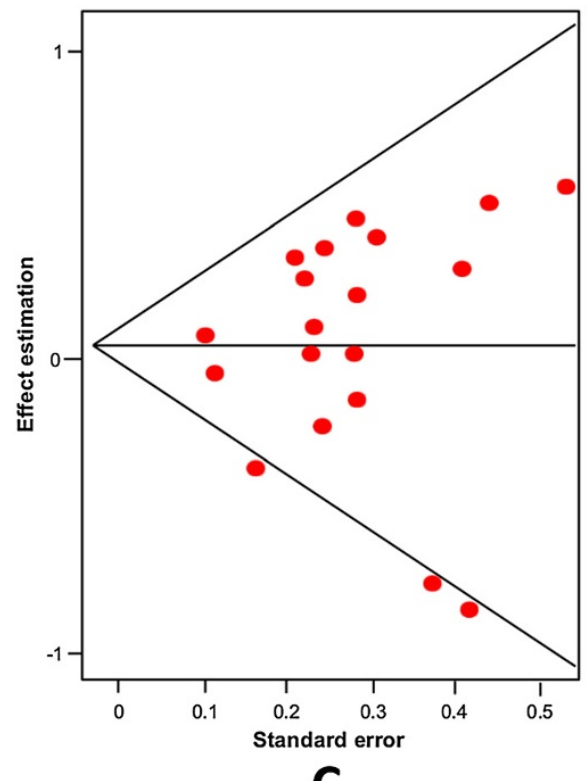

C

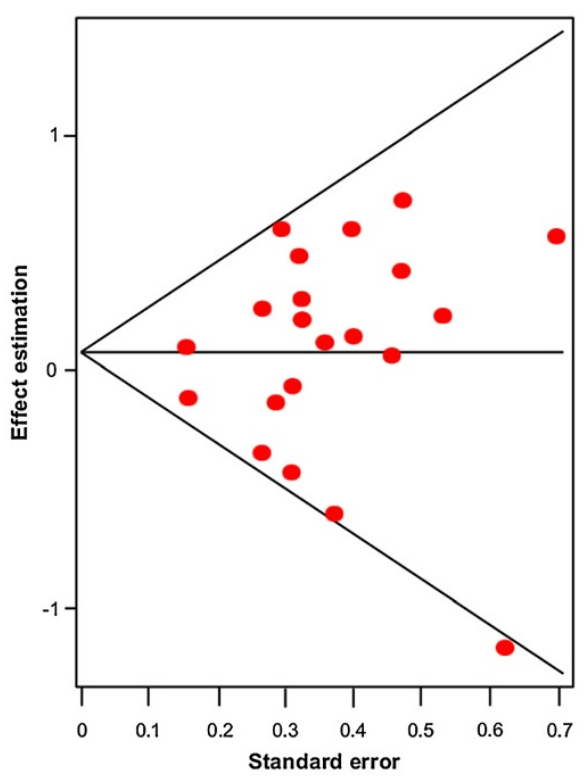

B

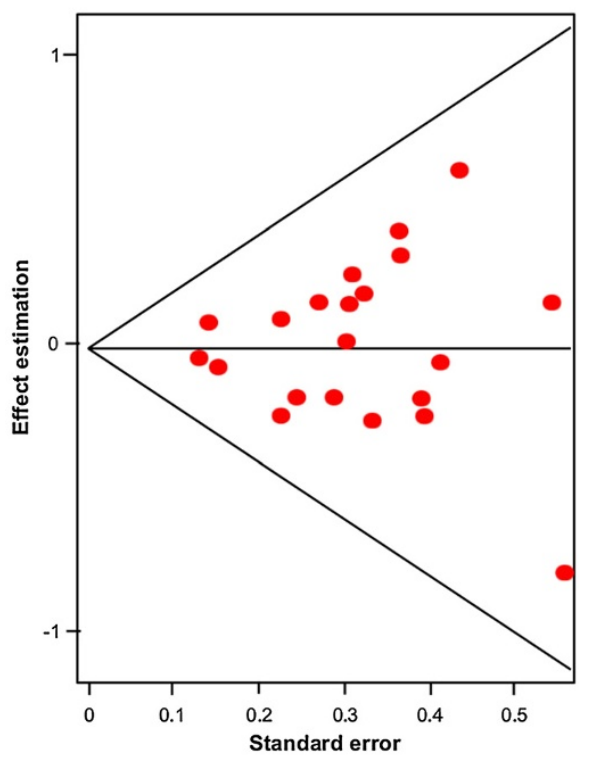

D

Figure 4 Egger's funnel plots indicating publication bias in studies on suicidal behavior and the A218C variant without heterogeneity, using the following models: A) Allelic; B) Additive; C) Dominant, and D) Recessive models. 
epidemiologic analysis of tabulated data. Data were analyzed with the random-effects and fixed effects models following the reports in the literature [63-65]. Sample heterogeneity was analyzed with the Dersimonian and Laird's Q test. Q test results were complemented with graphs to help the visualization of those studies favoring heterogeneity. The studies outside the heterogeneity curve were excluded. The results of the meta-analysis are expressed as odds ratios (ORs). Pooled ORs were calculated respectively for each of the models used, viz: allelic (Example: A vs. C), additive (AA vs. CC), dominant $(\mathrm{AA}+\mathrm{AC}$ vs. $\mathrm{CC}$ ), and recessive (AA vs. $\mathrm{AC}+\mathrm{CC})$. Also, we analyzed TPH1 and TPH2 gene variants by Caucasian and Asian populations. To address the problem of publication bias, the Egger's test and funnel plots were calculated with the EPIDAT 3.1 software. This plotting standardizes the effect of each of the published studies on the vertical axis and its correspondent precision on the horizontal axis. Also, we evaluated publication bias using the GRADE approach and assessed the risk for bias. Finally, a chi-squared $\left(x^{2}\right)$ analysis was used to calculate the Hardy-Weinberg equilibrium to evaluate genotype distribution. Studies deemed for inclusion in the systematic review were scored for methodological

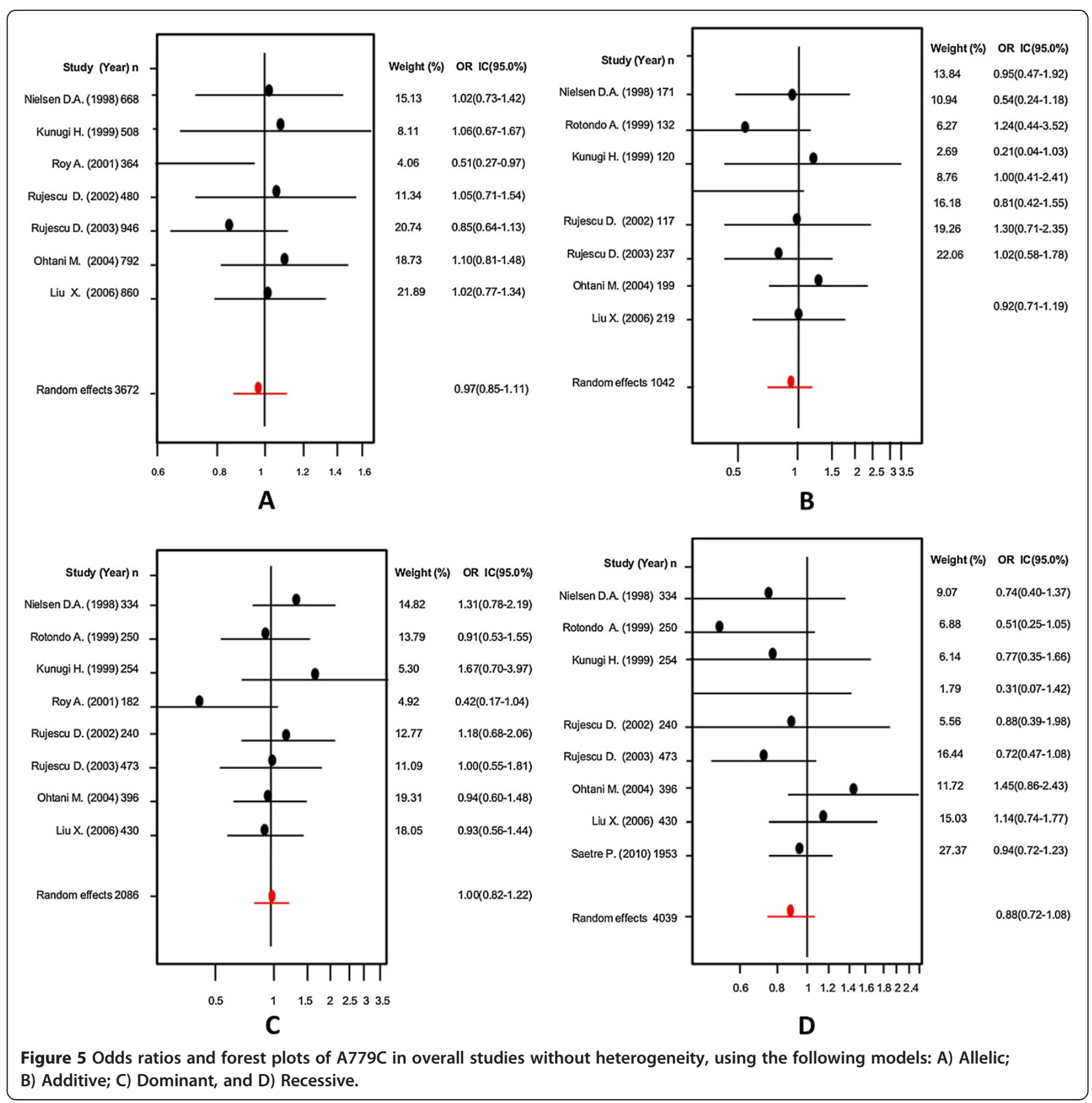


quality using the Newcastle-Ottawa Assessment Scale (NOS). A score of six or more was taken as the cut-off point to distinguish high from low quality studies [66] (see Additional file 1).

\section{Results}

We measured the Hardy-Weinberg equilibrium (HWE) in both groups (cases and controls) for all the samples of TPH genes; we also explored all populations in a combined way. Results are shown in Tables 1 and 2.

\section{TPH-1 gene variants}

\section{A218C polymorphism}

Firstly, an analysis of the variant A218C (rs1800532) of the TPH-1 gene was performed. In this study we evaluated the role of this variant in several models: allelic, additive, dominant and recessive. Also, we considered the Caucasian and Asian populations separately, using the same four models. And as in a previous meta-analysis [18,22-25], we found a positive association of $\mathrm{A} 218 \mathrm{C}$ variant with $\mathrm{SB}$ in the fixed effects model, but not in the random effects

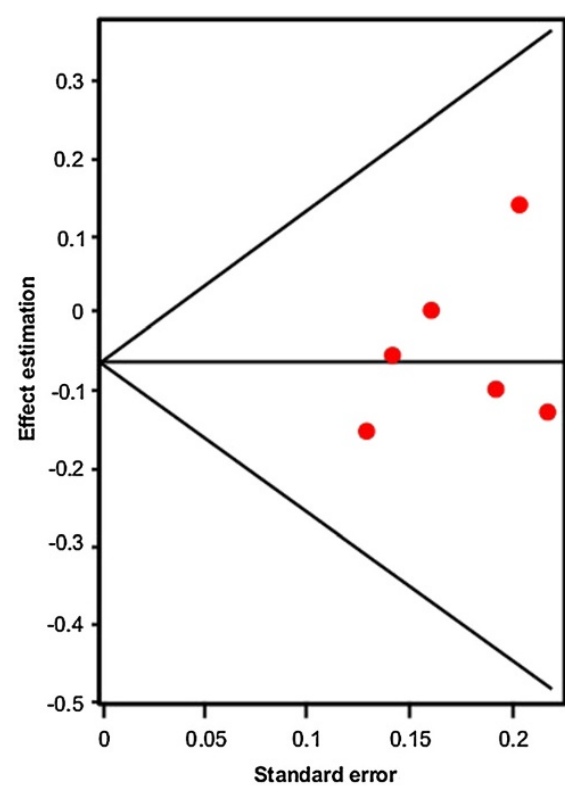

A

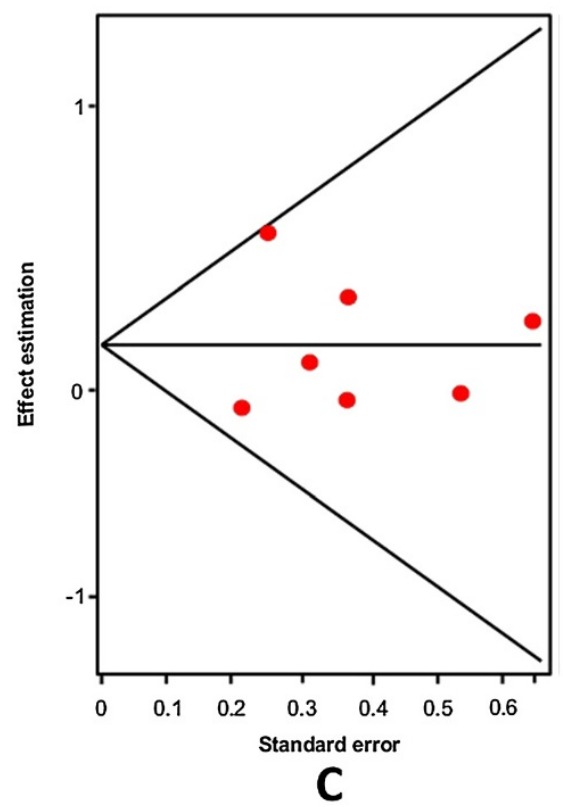

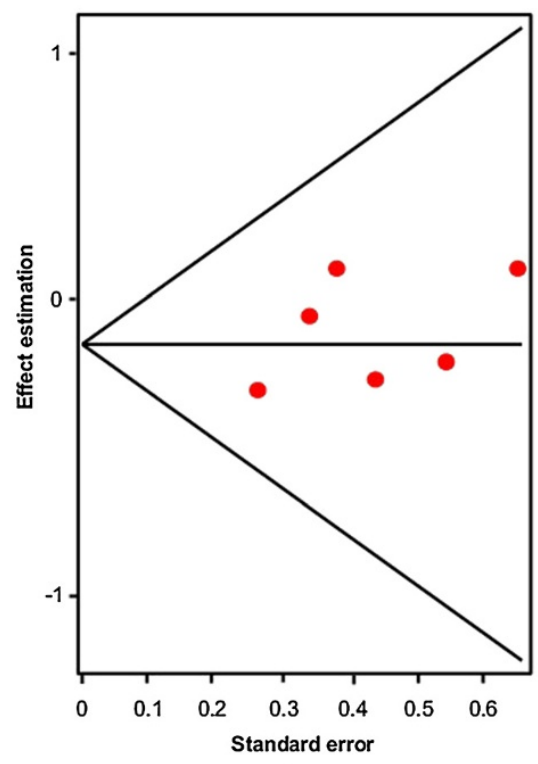

B

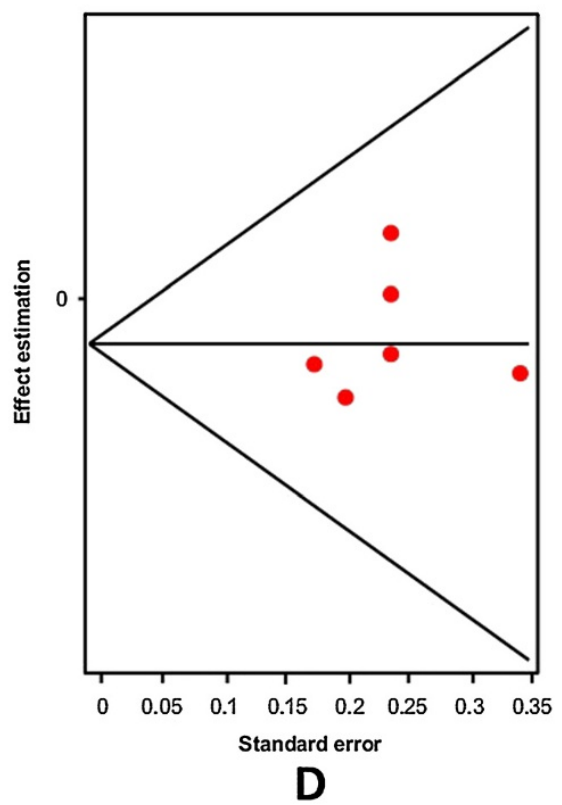

Figure 6 Egger's funnel plots indicating publications bias in studies on suicidal behavior and the A779C variant without heterogeneity, using the following models: A) Allelic; B) Additive; C) Dominant, and D) Recessive models. 
model. Our results are presented in Table 3. Figures 3 and 4 present the forest plots and Egger's test of the same four models previously mentioned (allelic, additive, dominant and recessive).

\section{A779C polymorphism}

With this variant we conducted the same analyses than in the previous variant gene (A218C). We observed a significant association with suicidal behavior, using the fixed effects model. This analysis was extended to Caucasian and Asian populations treated separately. Table 3 shows in more detail the analysis of this variant gene in all the models tested (allelic, additive, recessive and dominant). Figures 5 and 6 present forest plots and Egger's tests in the same models.

\section{TPH-2 gene variants}

\section{G703T polymorphism}

The first variant analyzed was the G-703 T (rs4570625) polymorphism. Initially, we explored the association of the $\mathrm{G}$ allele and patients with SB; we did not find significant differences (Random effects: OR: 1.02; 95\% CI 0.85-1.22; $\mathrm{p}(\mathrm{Z})=0.99)$. We observed heterogeneity in all studies $(\mathrm{Q}=12.43 ; \mathrm{df}=6 ; \mathrm{p}=0.04)$. The Egger's test provided no evidence of publication bias $(t=0.04 ; \mathrm{df}=5 ; \mathrm{p}=0.96)$ (see Additional file 1). Next, we excluded the study by Yoon and Kim [44], based on heterogeneity, and still we could not find any significant differences (Random effects: OR: 0.93; 95\% CI 0.81-1.06; $\mathrm{p}(\mathrm{Z})=0.70$; Figure 7A; $\mathrm{Q}$ test $=$ $1.73 ; \mathrm{df}=5 ; \mathrm{p}=0.88)$. Also, there was no evidence of publication bias (Egger's test: $\mathrm{t}=1.01, \mathrm{df}=4 ; \mathrm{p}=0.36$; Figure 8A). The same results were found when we used the additive model without heterogeneity (Random effects: OR: 0.88; 95\% CI 0.65-1.20; $\mathrm{p}(\mathrm{Z})=0.45$; Figure 7B; $\mathrm{Q}$ test $=1.65$; $\mathrm{df}=6 ; \mathrm{p}=0.89)$. No evidence of publication bias was encountered (Egger's test $t=1.03 ; \mathrm{df}=5 ; \mathrm{p}=0.36$; Figure $8 \mathrm{~B}$ ). We did not find any significant differences when we used the dominant model without heterogeneity either (Random effects: OR: 1.07; 95\% CI 0.84-1.38; $\mathrm{p}(\mathrm{Z})=0.76$; Figure 7C; $\mathrm{Q}$ test $=6.43 ; \mathrm{df}=6 ; \mathrm{p}=0.37$ ). Similarly, no evidence of publication bias was observed (Egger's test: $\mathrm{t}=0.24, \mathrm{df}=5 ; \mathrm{p}=$ 0.83 ; Figure 8). Finally, the same negative results were found in the recessive model without heterogeneity (Random effects: OR: 0.91; 95\% CI 0.76-1.09; $\mathrm{p}(\mathrm{Z})=0.45$; $\mathrm{Q}$ test $=1.76$; $\mathrm{df}=6 ; \mathrm{p}=0.88$; Figure 7D). No evidence of publication bias was encountered (Egger's test: $t=0.46 ; d f=5 ; p=0.66$; Figure $8 D$ ). In addition, we conducted the same analyses using the allelic, additive, dominant and recessive models in Asian and Caucasian populations, separately. However, we could not find any significant differences (Table 4).

\section{A473T polymorphism}

Also, we conducted an analysis of allele A of the A-473 T (rs11178997) polymorphism in association with SB and

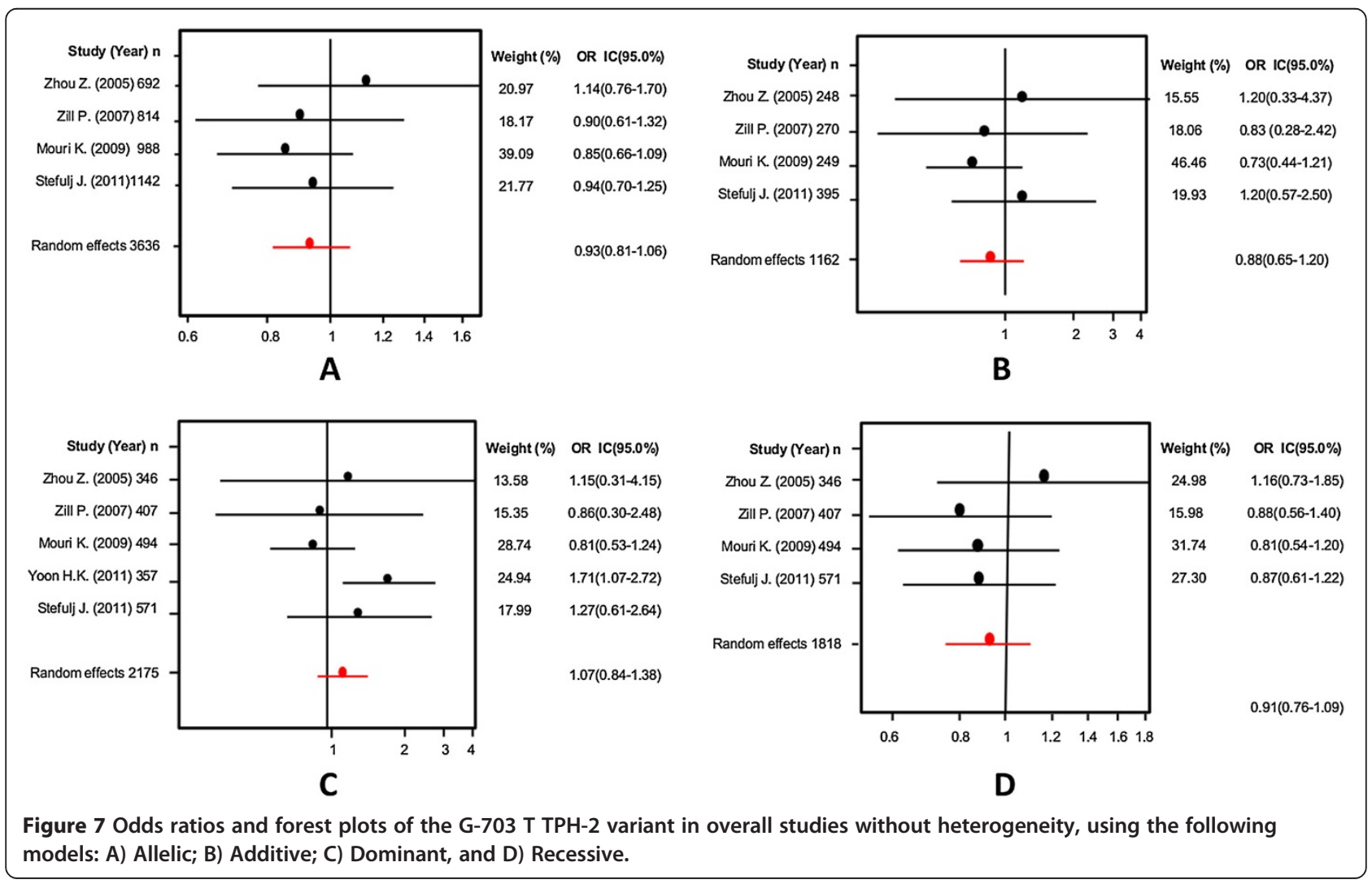




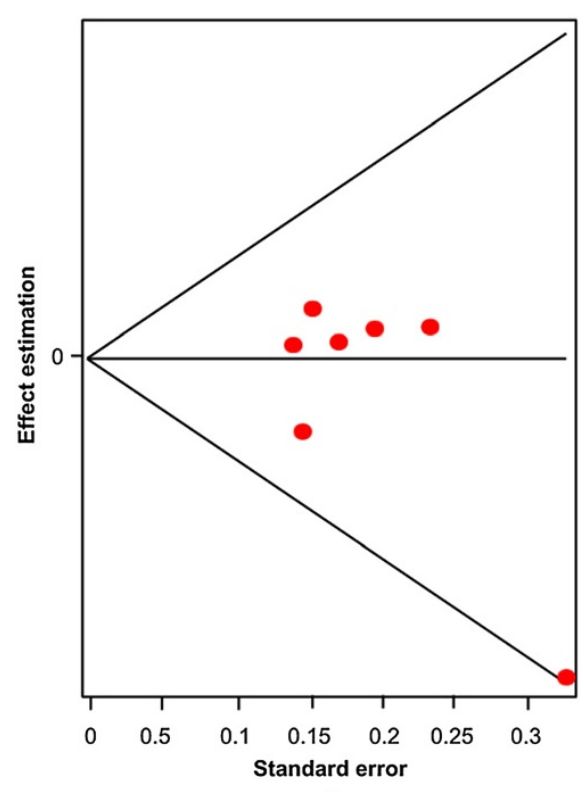

A

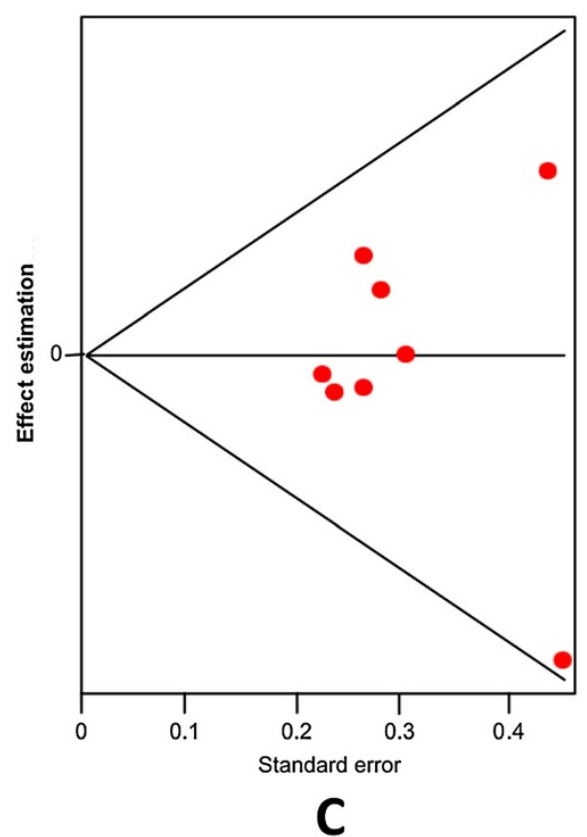

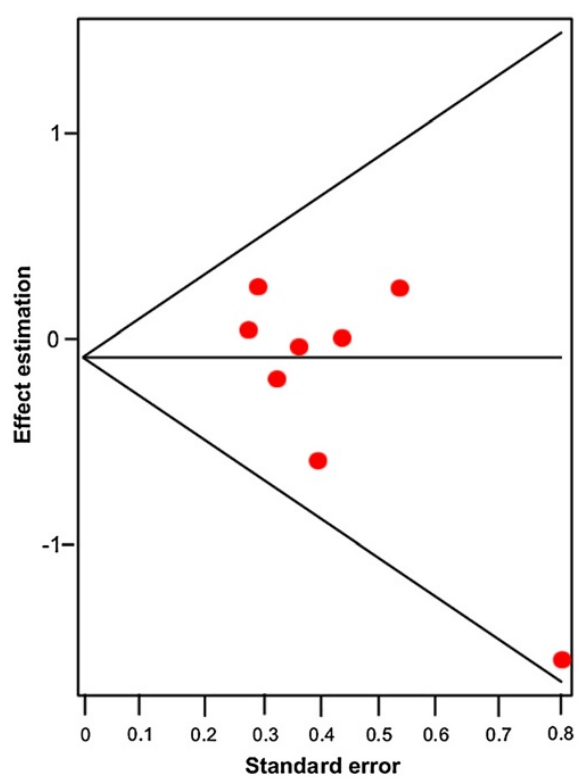

B

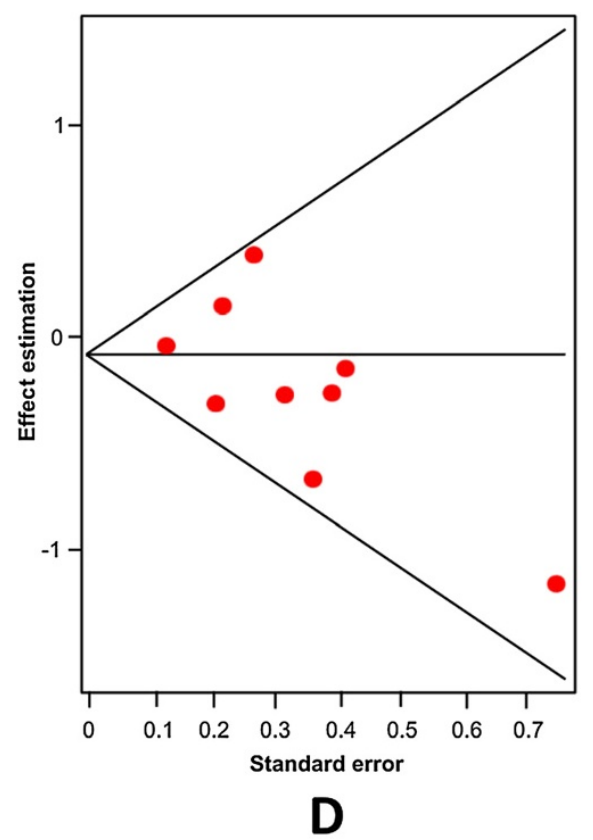

Figure 8 Egger's funnel plots indicating publication bias in studies on suicidal behavior and the G-703 T TPH-2 variant without heterogeneity, using the following models: A) Allelic; B) Additive; C) Dominant, and D) Recessive.

we found the same negative results with heterogeneity (Random effects: OR: 0.89; 95\% CI 0.63-1.26; $\mathrm{p}(\mathrm{Z})=0.98$; $\mathrm{Q}$ test $=18.81 \mathrm{df}=5 ; \mathrm{p}=0.002)$. No evidence of publication bias was found (Egger's test $\mathrm{t}=0.83, \mathrm{df}=4 ; \mathrm{p}=0.44$ ). Next, we eliminated heterogeneity by excluding the study by Zhou et al. [61] in a Caucasian population (Random effects: OR:0.76; 95\% CI 0.61-0.95; $\mathrm{p}(\mathrm{Z})=0.80$; $\mathrm{Q}$ test $=$ 4.54; $\mathrm{df}=4 ; \mathrm{p}=0.33$; Figure $9 \mathrm{~A}$ ) and found no significant differences. Besides, we did not encounter evidence of publication bias (Egger's test: $\mathrm{t}=1.04 ; \mathrm{df}=3 ; \mathrm{p}=0.37$; Figure 10A). When we used the additive model, we excluded the studies by Zupanc et al. [19] and Zhou et al. [61] in the Caucasian population given that some frequencies were equal to zero. Still, we did not find any significant differences without heterogeneity (Random effects: OR: 1.00; 95\% CI 0.52-1.93; $\mathrm{p}(\mathrm{Z})=0.73$; Figure 9B; $\mathrm{Q}$ test $=2.91$; $\mathrm{df}=3 ; \mathrm{p}=0.40$ ); also we did not encounter evidence of publication bias (Egger's test: $\mathrm{t}=0.36, \mathrm{df}=2 ; \mathrm{p}=0.74$; 
Table 4 Meta-analysis of case-control studies on G-703 T/ A-473 T/G19918A TPH-2 gene variants and SB by populations

\begin{tabular}{|c|c|c|c|c|c|c|c|c|c|c|c|c|c|}
\hline \multicolumn{2}{|c|}{ Model analysis } & \multicolumn{2}{|c|}{ G703T } & $\begin{array}{l}P \text { value } \\
\text { of } Q \text { test }\end{array}$ & $\begin{array}{l}\text { P value } \\
\text { of Egger's } \\
\text { test }\end{array}$ & \multicolumn{2}{|c|}{ A473T } & $\begin{array}{l}P \text { value } \\
\text { of } Q \text { test }\end{array}$ & $\begin{array}{l}\text { P value } \\
\text { of Egger's } \\
\text { test }\end{array}$ & \multicolumn{2}{|c|}{ G19918A } & $\begin{array}{l}P \text { value } \\
\text { of } Q \text { test }\end{array}$ & $\begin{array}{l}\text { P value } \\
\text { of Egger's } \\
\text { test }\end{array}$ \\
\hline \multicolumn{14}{|c|}{ Caucasian population } \\
\hline \multirow[t]{2}{*}{ Allelic } & $\begin{array}{l}\text { With } \\
\text { heterogeneity }\end{array}$ & $0.95(0.79-1.14)$ & $0.95(0.79-1.14)$ & 0.91 & 0.72 & $0.95(0.79-1.14)$ & $0.95(0.79-1.14)$ & 0.91 & 0.72 & $1.12(0.88-1.43)$ & $1.09(0.95-1.25)$ & 0.04 & 0.59 \\
\hline & $\begin{array}{l}\text { Without } \\
\text { heterogeneity }\end{array}$ & & & & & & & & & $0.99(0.85-1.16)$ & $0.99(0.851 .16)$ & 0.52 & 0.57 \\
\hline \multirow[t]{2}{*}{ Additive } & $\begin{array}{l}\text { With } \\
\text { heterogeneity }\end{array}$ & $1.03(0.66-1.62)$ & $1.03(0.6-61.62)$ & 0.84 & 0.56 & $1.03(0.66-1.62)$ & $1.03(0.66-1.62)$ & 0.84 & 0.56 & $1.45(0.87-2.40)$ & $1.45(0.87-2.40)$ & 0.44 & 0.95 \\
\hline & $\begin{array}{l}\text { Without } \\
\text { heterogeneity }\end{array}$ & & & & & & & & & & & & \\
\hline \multirow[t]{2}{*}{ Dominant } & $\begin{array}{l}\text { With } \\
\text { heterogeneity }\end{array}$ & $1.05(0.68-1.62)$ & $1.05(0.68-1.62)$ & 0.79 & 0.79 & $1.05(0.68-1.62)$ & $1.05(0.68-1.62)$ & 0.79 & 0.79 & $1.18(0.79-1.76)$ & $1.14(0.80-1.64)$ & 0.35 & 0.33 \\
\hline & $\begin{array}{l}\text { Without } \\
\text { heterogeneity }\end{array}$ & & & & & & & & & & & & \\
\hline \multirow[t]{2}{*}{ Recessive } & $\begin{array}{l}\text { With } \\
\text { heterogeneity }\end{array}$ & $0.91(0.72-1.15)$ & $0.91(0.72-1.15)$ & 0.86 & 0.54 & $0.91(0.72-1.15)$ & $0.91(0.72-1.15)$ & 0.86 & 0.54 & $1.15(0.86-1.55)$ & $1.09(0.93-1.29)$ & 0.06 & 0.59 \\
\hline & $\begin{array}{l}\text { Without } \\
\text { heterogeneity }\end{array}$ & & & & & & & & & $0.98(0.81-1.18)$ & $0.98(0.81-1.18)$ & 0.60 & 0.52 \\
\hline \multicolumn{14}{|c|}{ Asian population } \\
\hline \multirow[t]{2}{*}{ Allelic } & $\begin{array}{l}\text { With } \\
\text { heterogeneity }\end{array}$ & $1.08(0.78-1.50)$ & $1.08(0.92-1.27)$ & 0.01 & 0.93 & & & & & & & & \\
\hline & $\begin{array}{l}\text { Without } \\
\text { heterogeneity }\end{array}$ & $0.91(0.75-1.11)$ & $0.91(0.75-1.11)$ & 0.47 & 0.58 & & & & & & & & \\
\hline \multirow[t]{2}{*}{ Additive } & $\begin{array}{l}\text { With } \\
\text { heterogeneity }\end{array}$ & $1.14(0.57-2.27)$ & $1.14(0.81-1.60)$ & 0.01 & 0.99 & & & & & & & & \\
\hline & $\begin{array}{l}\text { Without } \\
\text { heterogeneity }\end{array}$ & $0.78(0.51-1.17)$ & $0.78(0.511 .17)$ & 0.78 & 0.29 & & & & & & & & \\
\hline \multirow[t]{2}{*}{ Dominant } & $\begin{array}{l}\text { With } \\
\text { heterogeneity }\end{array}$ & 1.09(0.82-1.44) & $1.09(0.82-1.44)$ & 0.11 & 0.94 & & & & & & & & \\
\hline & $\begin{array}{l}\text { Without } \\
\text { heterogeneity }\end{array}$ & & & & & & & & & & & & \\
\hline \multirow[t]{2}{*}{ Recessive } & $\begin{array}{l}\text { With } \\
\text { heterogeneity }\end{array}$ & $1.13(0.74-1.70)$ & $1.11(0.87-1.41)$ & 0.03 & 0.86 & & & & & & & & \\
\hline & $\begin{array}{l}\text { Without } \\
\text { heterogeneity }\end{array}$ & $0.93(0.70-1.22)$ & $0.93(0.70-1.22)$ & 0.48 & 0.94 & & & & & & & & \\
\hline
\end{tabular}




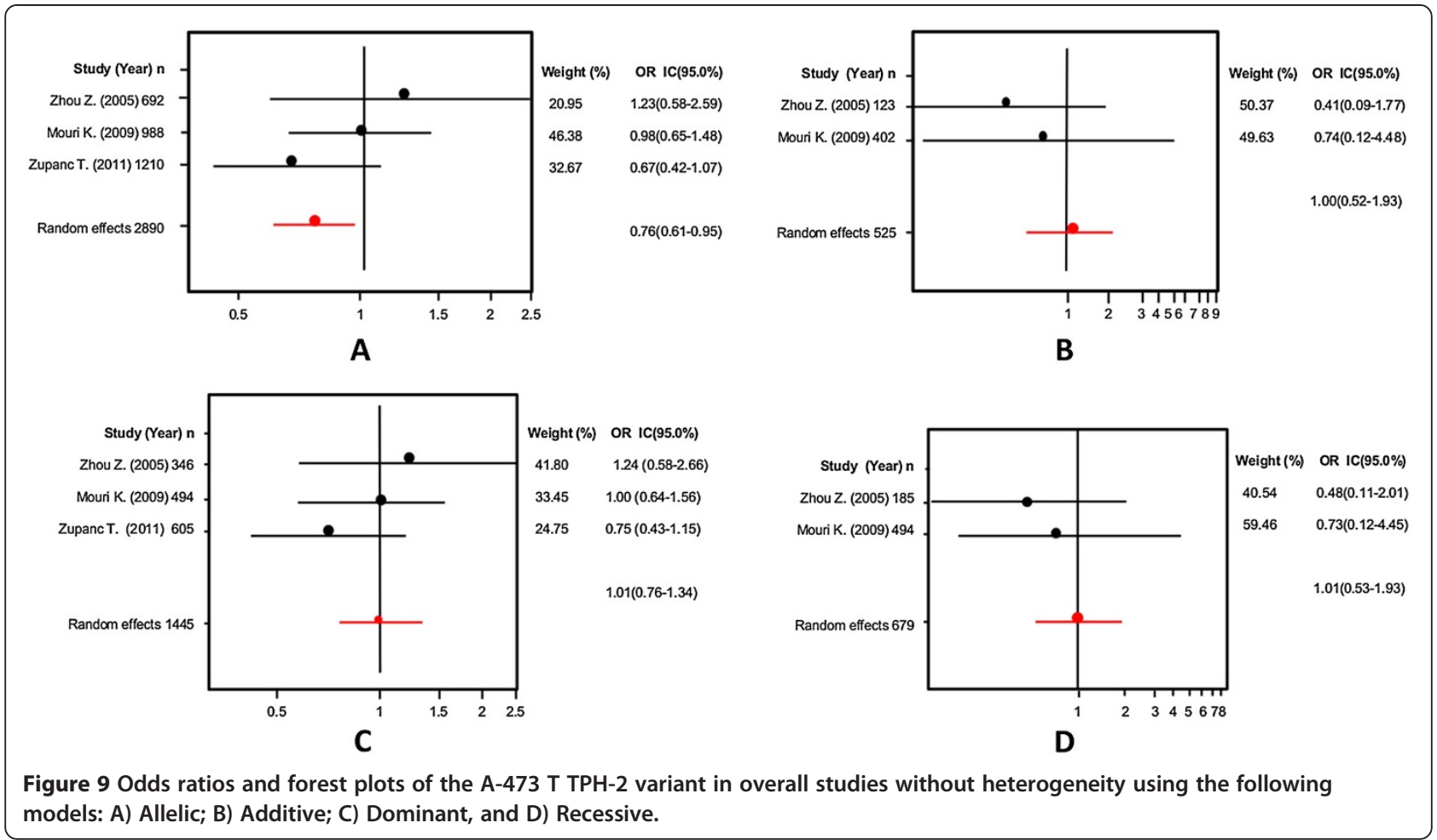

Figure 10B). A negative result was also found for the dominant model without heterogeneity (Random effects: OR: 1.01; 95\% CI 0.76-1.34; $\mathrm{p}(\mathrm{Z})=0.70$; Figure 9C; $\mathrm{Q}$ test $=10.46 ; \mathrm{df}=5 ; \mathrm{p}=0.06$ ); no evidence of publication bias was encountered (Egger's test: $\mathrm{t}=1.74 ; \mathrm{df}=4$; $p=0.15$; Figure $10 \mathrm{C}$ ). The same negative results were obtained with the recessive model without heterogeneity excluding the studies by Zupanc et al. [19] and Zhou et al. [61] in the Caucasian population because some frequencies were equal to zero (Random effects: OR:1.01; 95\% CI 0.53-1.93; $\mathrm{p}(\mathrm{Z})=0.73$; Figure 9D; $\mathrm{Q}$ test $=2.33$; $\mathrm{df}=3 ; \mathrm{p}=0.50)$; there was no evidence of publication bias (Egger's test: $t=0.31 ; \mathrm{df}=2 ; \mathrm{p}=0.78$; Figure 10D). In addition, with regard to the analysis of the A-473 $\mathrm{T}$ variant of the TPH-2 gene in relation to SB, we conducted an analysis in the Caucasian population, using the same four models as above and could not find any significant differences (Table 4).

\section{G19918A polymorphism}

Finally, the G19918A (rs1386494) polymorphism was the last variant studied in association with SB. When we analyzed allele $\mathrm{G}$ vs allele A, we could not find any significant differences in the analysis without heterogeneity (Random effects: OR: 1.09; 95\% CI 0.91-1.31; $\mathrm{p}(\mathrm{Z})=0.98$; Figure 11A; $\mathrm{Q}$ test $=10.32 ; \mathrm{df}=5 ; \mathrm{p}=0.06$ ); we found no evidence of publication bias (Egger's test: $t=0.78$; $\mathrm{df}=4$; $\mathrm{p}=0.47$; Figure 12A). Subsequently, we performed an analysis with the additive model without heterogeneity
(Random effects: OR: 1.45; 95\% CI 0.87-2.40; $\mathrm{p}(\mathrm{Z})=0.80$; Figure 11B; $\mathrm{Q}$ test $=3.70 ; \mathrm{df}=4 ; \mathrm{p}=0.44)$; we found no evidence of publication bias (Egger's test: $t=0.09 ; \mathrm{df}=3$; $p=0.95$, Figure $12 B$ ). The same negative outcome was found when using the dominant model without heterogeneity (Random effects: OR: 1.18; 95\% CI 0.79-1.76; p $(\mathrm{Z})=0.80$; Figure $11 \mathrm{C}$; $\mathrm{Q}$ test $=4.38 ; \mathrm{df}=4 ; \mathrm{p}=0.35$ ); no evidence of publication bias was found (Egger's test: $\mathrm{t}=$ $1.14 ; \mathrm{df}=3 ; \mathrm{p}=0.33$; Figure $12 \mathrm{C}$ ). The same result was obtained with the recessive model without heterogeneity (Random effects: OR: 1.16; 95\% CI 0.90-1.50; $\mathrm{p}(\mathrm{Z})=0.45$; Figure 11D; $\mathrm{Q}$ test $=9.12 ; \mathrm{df}=5 ; \mathrm{p}=0.10$ ); no evidence of publication bias was encountered (Egger's test: $t=0.74$; $\mathrm{df}=4 ; \mathrm{p}=0.49$; Figure 12D). Finally, we conducted an analysis in the Caucasian population separately using the same four models as in the other polymorphism, and could not find any significant differences (Table 4).

\section{Discussion}

In this study, we explored the association of THP-1 and TPH-2 gene polymorphisms with suicidal behavioral. We found an association between A218C/ATT9C polymorphism of TPH1 and suicidal behavior. However, we could not find an association between TPH2 gene variants and this behavior. To our knowledge, this is the first study evaluating TPH2 gene variants and suicidal behavior.

Suicide has become a serious problem around the world. Various published studies show the search for possible genetic markers that could help in the early 


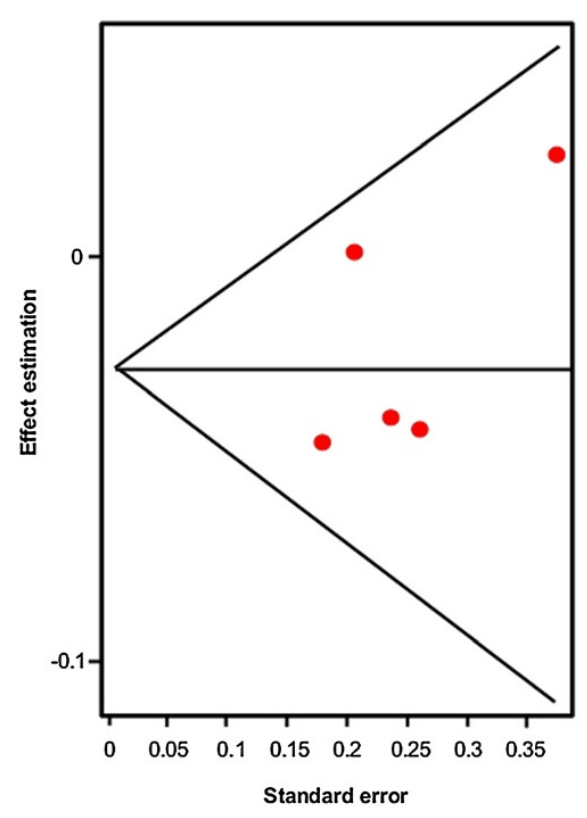

A

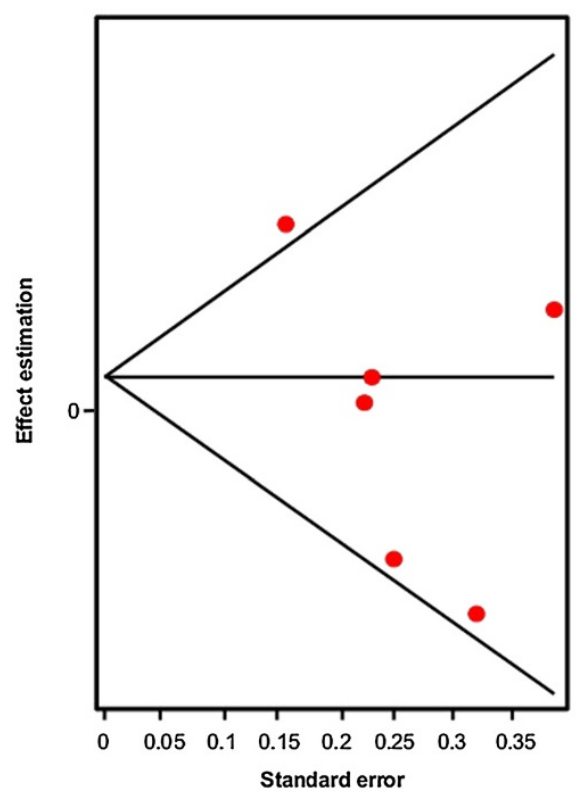

C

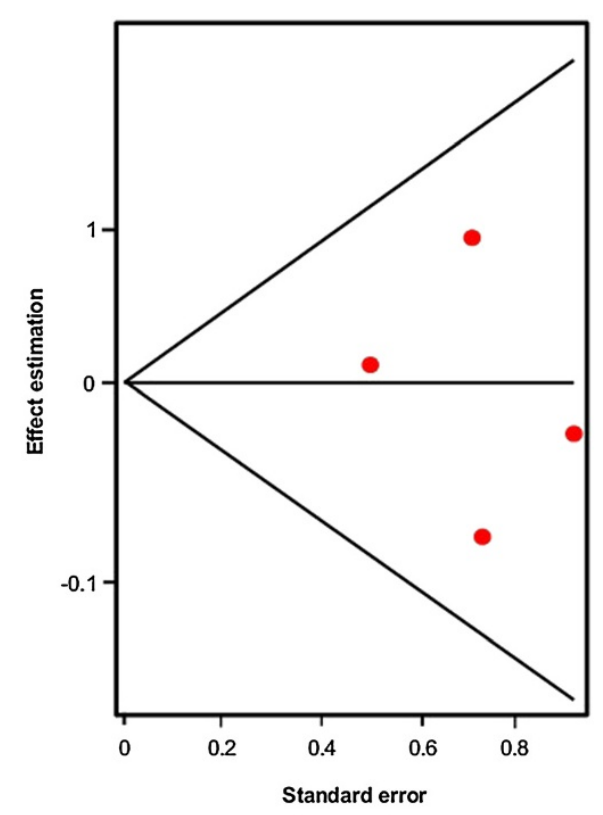

B

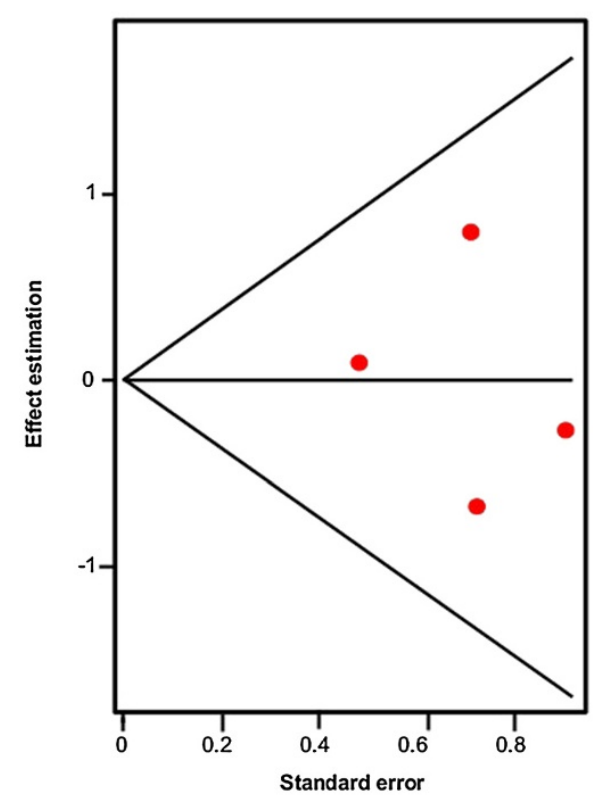

D

Figure 10 Egger's funnel plots indicating publication bias in studies on suicidal behavior and the A-473 T TPH-2 variant without heterogeneity, using the following models: A) Allelic; B) Additive; C) Dominant, and D) Recessive.

detection and prevention of suicidal behavior [13,67,68]. One possible mechanism by which genetic factors may affect the risk for suicide is through the control of serotonergic neurotransmission. TPH genes have been proposed as the main candidate genes in association studies on suicidal behavior, given that the TPH enzyme is a ratelimiting step in serotonin biosynthesis. Despite the increasing amount of genetic association studies on SB, the results are inconclusive. Therefore, we performed a meta-analysis in order to evaluate the association of TPH-1 and TPH-2 genes with SB in which we integrated the outcomes of the different polymorphic markers and different ethnic groups. Initially, although variants A218C (rs1800532) and A779C (rs1799913) of the TPH-1 gene have been studied in relation to suicidal behavior in different meta-analyses [18,22-25], we analyzed the TPH-1 gene 

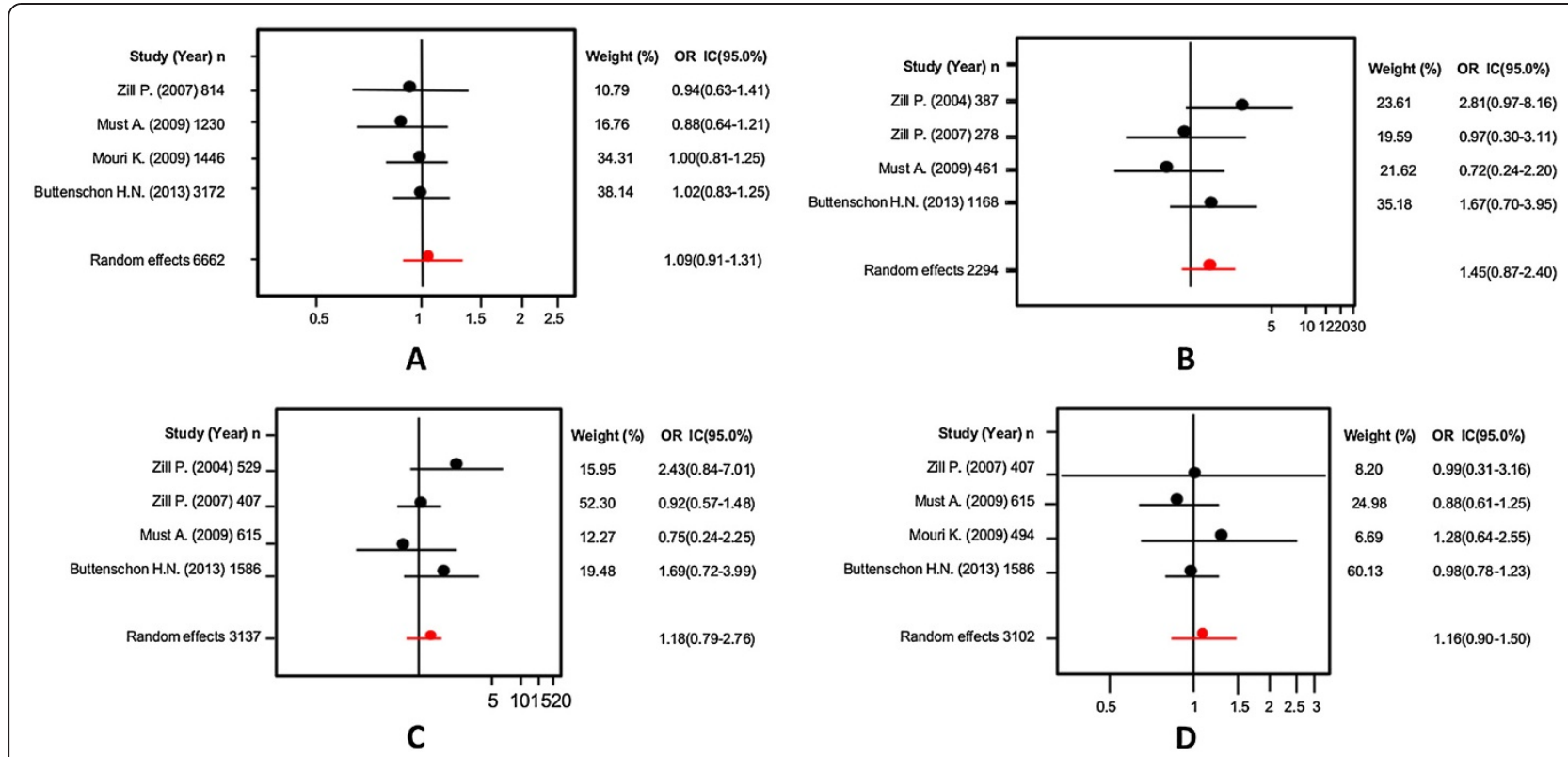

Figure 11 Odds ratios and forest plots of the G19918A TPH-2 variant in overall studies without heterogeneity, using the following models: A) Allelic; B) Additive; C) Dominant, and D) Recessive.

in patients with SB. The evaluated variants of this gene were A779C (rs1799913) and A218C (rs1800532); these two polymorphisms are the most studied of the TPH-1 gene and with interesting outcomes. We not only analyzed allele $A$ vs allele $C$, but also evaluated the association using three other models: additive, dominant and recessive in a pool population that combined the genetic studies of TPH-1 variants. In addition, we performed a sub-group analysis in Caucasian and Asian populations separately to evaluate the association of A779C (rs1799913) and A218C (rs1800532) polymorphisms with SB using the same four models. Our results are in agreement with previous metaanalyses [18,22-25]. These studies report a strong association with SB using the fixed effects model. In the present meta-analysis we also found an association when we used the fixed effects model, but not with the random effects model. However, this result should be taken with caution because the random effects model is more conservative than the fixed effects one. The latter assumes the same true genetic effects, and the former supposes normally distributed effects and parametrizes inter-studies variations. To get a clearer panorama of the possible role of these variants in $\mathrm{SB}$, we summarized the results of our analyses in Tables 3 and 4 . The evidence suggests that TPH-1 A218C/A779C polymorphisms may be associated with increased susceptibility to present SB clinically.

On the other hand, to explore the association of SB with TPH-2 gene, we chose rs4570625 (G-703 T), rs11178997 (A-473 T) and rs1386494 (G19918A) variants, given their functionality and the extensive amount of studies evaluating these polymorphisms in association with SB. We performed the analysis with the same four models used for the TPH1-gene: allelic, additive, dominant, and recessive. We also conducted a sub-group analysis in the Caucasian and Asian populations utilizing the same previously mentioned models. In the present study we could not find any association in any of the models, but we found a slight protective effect concerning polymorphism A-473 $\mathrm{T}$ toward suicidal behavior in the recessive model (Random effects: OR: 0.76; 95\% CI 0.61-0.95; $\mathrm{p}(\mathrm{Z})=0.80$; $\mathrm{Q}$ test $=4.54 ; \mathrm{df}=4 ; \mathrm{p}=0.33$ ); no evidence of publication bias was encountered (Egger's test: $t=1.04 ; \mathrm{df}=3 ; \mathrm{p}=0.37$ ).

There are several explanations for the present outcomes concerning the lack of association of TPH-2 variants with SB. First, the criteria used in the selection of the control groups differ among studies. Second, although the subjects were patients with SB, there were differences in the diagnoses (attempted, ideation and completed suicide, and exclusion criteria of neuropsychiatric diseases, among other factors). For example, Souery et al. [37] work with patients with bipolar disorder that present SB, Yoon and Kim [44] with depressive subjects and SB, Paik et al. [45] with schizophrenic patients, and Turecki et al. [39] with suicide completers only. Other possibility is genetic heterogeneity: some authors have shown that the distribution of the frequencies of $\mathrm{TPH}-2$ variants may depend on ethnicity. Therefore, we evaluated the association of TPH2 variants with SB in several populations. The fourth explanation considers the presence of other genes which may interact with $\mathrm{TPH}-2$ to increase the risk to present $\mathrm{SB}$ clinically. We also want to emphasize the relevance of employing larger sample 


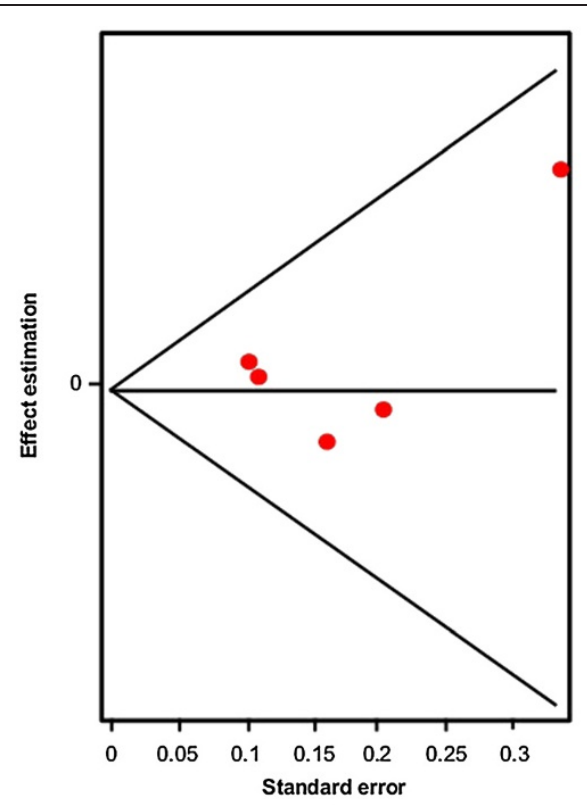

A

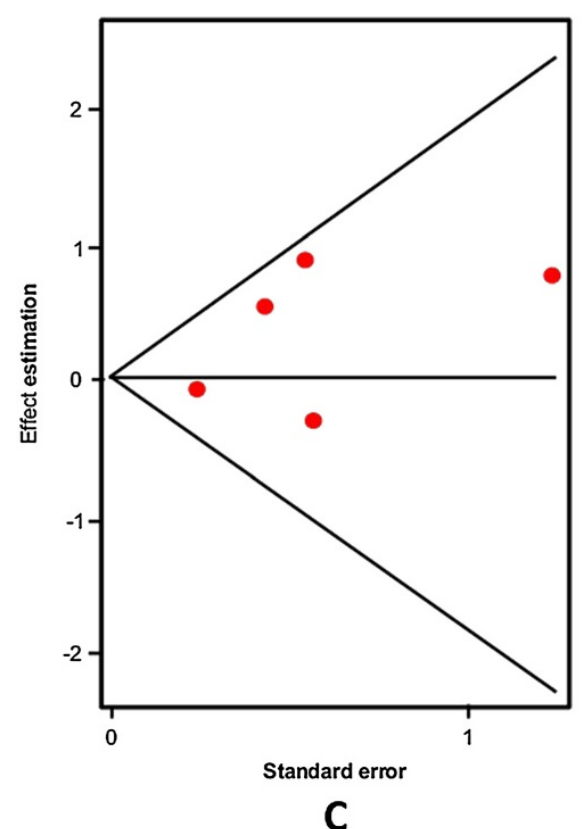

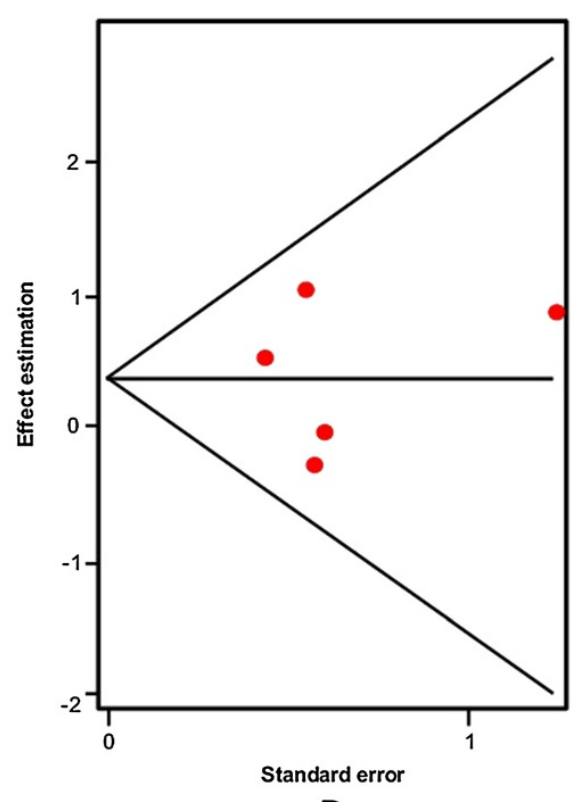

B

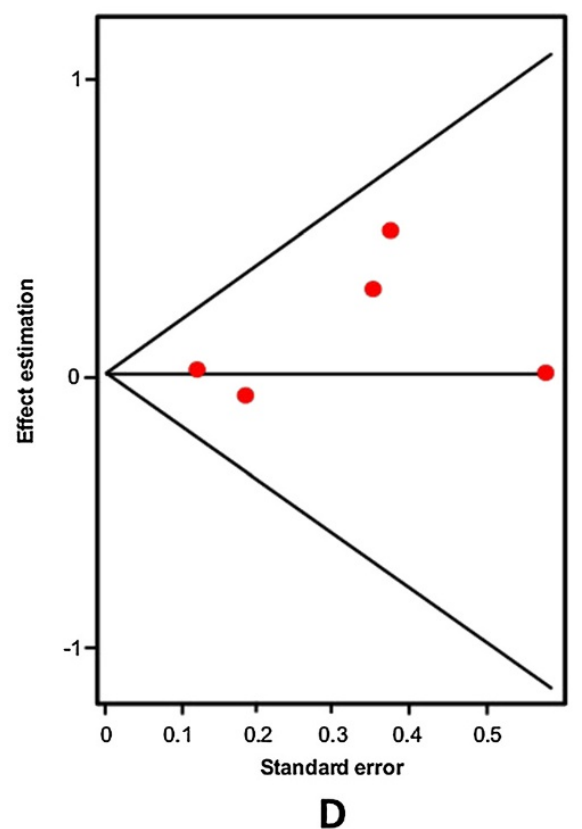

Figure 12 Egger's funnel plots indicating publication bias in studies on suicidal behavior and the G19918A TPH-2 variant without heterogeneity, using the following models: A) Allelic; B) Additive; C) Dominant, and D) Recessive.

sizes to enable the observation of more conclusive results.

This study has some limitations. First, we performed the present meta-analysis based only on published studies. We considered that by selecting only published results, we ensured that our meta-analysis excluded poorly designed studies. Second, although the present analysis involves a large number of studies and genetic variants, it is relatively small in comparison with other meta-analysis on different diseases. Also, we could not perform an analysis including suicide ideation, suicide attempt, or completed suicide. Other limitation is that we did not stratify the analysis by gender because it was not always possible to obtain all the data from the reports or directly from the authors. Also, we did not perform the analysis of all the variants of the TPH-2 gene in the Asian population because there were not enough studies. Sixth, we did not evaluate SB endophenotypes or psychopathologies which could increase 
the risk for suicidal behavior. One last comment: is that although there are previous meta-analyses evaluating the association of the TPH-1 gene (A218C and A779C variants) and $\mathrm{SB}$, our study contains more recent data and the use of various types of models to perform the analysis.

\section{Conclusion}

In summary, we performed a meta-analysis to assess the association of A779C (rs1799913) and A218C (rs1800532) variants of the TPH-1 gene, and rs4570625 (G-703 T), rs11178997 (A-473 T), and rs1386494 (G19918A) of the TPH-2 gene with SB. Our analysis of TPH-1 provided evidence that $\mathrm{A} 218 \mathrm{C} / \mathrm{A} 779 \mathrm{C}$ TPH-1 variants may be risk factors to present $\mathrm{SB}$, which is in agreement with previously reported meta-analyses [18,22-25]. With regard to G-703 T/A-473 T/G19918A TPH-2 variants, our updated meta-analysis did not detect any significant association with patients presenting SB. However, these results should be interpreted with caution because not all the models detected this association and the sample size may be just enough to detect small effects of the polymorphisms. Further studies with larger samples in different ethnic populations need to be undertaken to confirm our findings.

\section{Additional file}

Additional file 1: Table S1. Summary finding of studies association between TPH1 gene variants and suicidal behavior. Table S2. Methodological quality of TPH1 gene variants studies association included based on the Newcastle-Ottawa scale.

\section{Competing interests}

The authors declare that they have no competing interests.

\section{Authors' contributions}

TZC and GCTB conceived the study, participated in its design and helped to draft the manuscript. TZC, JRI, and LNML helped to perform the statistical analysis and to draft the manuscript. All authors read and approved the final manuscript.

\section{Acknowledgements}

We want to thank the support of grants UJAT-DAMC-2012-02 from the University of Tabasco and CONACYT CB2012-177459.

\section{Author details}

'División Académica de Ciencias de la Salud, Universidad Juárez Autónoma de Tabasco, Villahermosa, Tabasco, México. ${ }^{2} \mathrm{CIGEN}$, Centro de Investigación Genómica, Comalcalco, Tabasco, México. ${ }^{3}$ Hospital General de Yajalón, Yajalón, Chiapas, México. ${ }^{4}$ División Multidisciplinaria de Comalcalco, Universidad Juárez Autónoma de Tabasco, Ranchería Sur, Cuarta Sección, C.P. 86650 Comalcalco, Tabasco, México.

Received: 28 January 2014 Accepted: 27 June 2014 Published: 8 July 2014

\section{References}

1. Bondy B, Buettner A, Zill P: Genetics of suicide. Mol Psychiatry 2006, 11(4):336-351

2. Souery D, Oswald $P$, Linkowski $P$, Mendlewicz J: Molecular genetics in the analysis of suicide. Ann Med 2003, 35(3):191-196.

3. Baldessarini RJ, Hennen J: Genetics of suicide: an overview. Harv Rev Psychiatry 2004, 12(1):1-13.
4. Lee DH, Noh EC, Kim YC, Hwang JY, Kim SN, Jang JH, Byun MS, Kang DH: Risk factors for suicidal ideation among patients with complex regional pain syndrome. Psychiatry Investig 2014, 11(1):32-38.

5. Lin SK, Hung TM, Liao YT, Lee WC, Tsai SY, Chen CC, Kuo CJ: Protective and risk factors for inpatient suicides: a nested case-control study. Psychiatry Res 2014, 217(1-2):54-59.

6. Weiland TJ, Cotter A, Jelinek GA, Phillips G: Suicide risk assessment in Australian emergency departments: assessing clinicians' disposition decisions. Psychiatry J 2014, 2014:943574.

7. Lester D: Genetics, twin studies, and suicide. Suicide Life Threat Behav 1986, 16(2):274-285

8. Voracek M, Loibl LM: Genetics of suicide: a systematic review of twin studies. Wien Klin Wochenschr 2007, 119(15-16):463-475.

9. Koller G, Engel RR, Preuss UW, Karakesisoglou A, Zill P, Bondy B, Soyka M: Tryptophan hydroxylase gene 1 polymorphisms are not associated with suicide attempts in alcohol-dependent individuals. Addict Biol 2005, 10(3):269-273.

10. Furlong RA, Ho L, Rubinsztein JS, Walsh C, Paykel ES, Rubinsztein DC: No association of the tryptophan hydroxylase gene with bipolar affective disorder, unipolar affective disorder, or suicidal behaviour in major affective disorder. Am J Med Genet 1998, 81(3):245-247.

11. New AS, Gelernter J, Yovell Y, Trestman RL, Nielsen DA, Silverman J, Mitropoulou V, Siever L: Tryptophan hydroxylase genotype is associated with impulsive-aggression measures: a preliminary study. Am J Med Genet 1998, 81(1):13-17.

12. El-Sayed AM, Haloossim MR, Galea S, Koenen KC: Epigenetic modifications associated with suicide and common mood and anxiety disorders: a systematic review of the literature. Biol Mood Anxiety Disord 2012, 2(1):2045-5380.

13. Antypa N, Serretti A, Rujescu D: Serotonergic genes and suicide: a systematic review. Eur Neuropsychopharmacol 2013, 23(10):1125-1142.

14. Bennett PJ, McMahon WM, Watabe J, Achilles J, Bacon M, Coon H, Grey T, Keller T, Tate D, Tcaciuc I, Workman J, Gray D: Tryptophan hydroxylase polymorphisms in suicide victims. Psychiatr Genet 2000, 10(1):13-17.

15. Booij L, Turecki G, Leyton M, Gravel P, Lopez De Lara C, Diksic M, Benkelfat C: Tryptophan hydroxylase(2) gene polymorphisms predict brain serotonin synthesis in the orbitofrontal cortex in humans. Mol Psychiatry 2012, 17(8):809-817.

16. Stefulj J, Kubat M, Balija M, Skavic J, Jernej B: Variability of the tryptophan hydroxylase gene: study in victims of violent suicide. Psychiatry Res 2005, 134(1):67-73.

17. Roy A, Rylander G, Forslund K, Asberg M, Mazzanti CM, Goldman D, Nielsen DA: Excess tryptophan hydroxylase 17779 C allele in surviving cotwins of monozygotic twin suicide victims. Neuropsychobiology 2001, 43(4):233-236.

18. Li D, He L: Further clarification of the contribution of the tryptophan hydroxylase (TPH) gene to suicidal behavior using systematic allelic and genotypic meta-analyses. Hum Genet 2006, 119(3):233-240.

19. Zupanc T, Pregelj P, Tomori M, Komel R, Paska AV: TPH2 polymorphisms and alcohol-related suicide. Neurosci Lett 2011, 490(1):78-81.

20. Zill P, Buttner A, Eisenmenger W, Moller HJ, Bondy B, Ackenheil M: Single nucleotide polymorphism and haplotype analysis of a novel tryptophan hydroxylase isoform (TPH2) gene in suicide victims. Biol Psychiatry 2004, 56(8):581-586.

21. Haghighi F, Bach-Mizrachi H, Huang YY, Arango V, Shi S, Dwork AJ, Rosoklija G, Sheng HT, Morozova I, Ju J, Russo JJ, Mann JJ: Genetic architecture of the human tryptophan hydroxylase 2 Gene: existence of neural isoforms and relevance for major depression. Mol Psychiatry 2008, 13(8):813-820.

22. Bellivier F, Chaste P, Malafosse A: Association between the TPH gene A218C polymorphism and suicidal behavior: a meta-analysis. Am J Med Genet B Neuropsychiatr Genet 2004, 1(1):87-91.

23. Saetre $P$, Lundmark $P$, Wang $A$, Hansen $T$, Rasmussen HB, Djurovic $S$, Melle I, Andreassen OA, Werge T, Agartz I, Hall H, Terenius L, Jonsson EG: The tryptophan hydroxylase 1 (TPH1) gene, schizophrenia susceptibility, and suicidal behavior: a multi-centre case-control study and meta-analysis. Am J Med Genet B Neuropsychiatr Genet 2010, 153B(2):387-396.

24. Rujescu D, Giegling I, Sato T, Hartmann AM, Moller HJ: Genetic variations in tryptophan hydroxylase in suicidal behavior: analysis and meta-analysis. Biol Psychiatry 2003, 54(4):465-473. 
25. Clayden RC, Zaruk A, Meyre D, Thabane L, Samaan Z: The association of attempted suicide with genetic variants in the SLC6A4 and TPH genes depends on the definition of suicidal behavior: a systematic review and meta-analysis. Transl Psychiatr 2012, 2(2):96.

26. Swartz MK: The PRISMA statement: a guideline for systematic reviews and meta-analyses. J Pediatr Health Care 2011, 25(1):1-2. doi: 10.1016/j. pedhc.2010.09.006.

27. Moher D, Liberati A, Tetzlaff J, Altman DG: Preferred reporting items for systematic reviews and meta-analyses: the PRISMA statement. Open Med 2009, 3(3):21.

28. Baud P, Perroud N, Courtet P, Jaussent I, Relecom C, Jollant F, Malafosse A: Modulation of anger control in suicide attempters by TPH-1. Genes Brain Behav 2009, 8(1):97-100.

29. Serretti A, Chiesa A: Treatment-emergent sexual dysfunction related to antidepressants: a meta-analysis. J Clin Psychopharmacol 2009, 29(3):259-266.

30. Kishi T, Yoshimura R, Fukuo Y, Okochi T, Matsunaga S, Umene-Nakano W Nakamura J, Serretti A, Correll CU, Kane JM, Iwata N: The serotonin 1A receptor gene confer susceptibility to mood disorders: results from an extended meta-analysis of patients with major depression and bipolar disorder. Eur Arch Psychiatry Clin Neurosci 2013, 263(2):105-118.

31. Calati R, Porcelli S, Giegling I, Hartmann AM, Möller H-J, De Ronchi D, Serretti A, Rujescu D: Catechol-o-methyltransferase gene modulation on suicidal behavior and personality traits: review, meta-analysis and association study. J Psychiatr Res 2011, 45(3):309-321.

32. Gonzalez-Castro TB, Tovilla-Zarate CA, Juarez-Rojop I, Pool Garcia S, Genis A, Nicolini H, Lopez Narvaez L: Association of 5HTR1A gene variants with suicidal behavior: case-control study and updated meta-analysis. J Psychiatr Res 2013, 30(13):00130-00131.

33. Tovilla-Zarate C, Juarez-Rojop I, Ramon-Frias T, Villar-Soto M, Pool-Garcia S, Medellin BC, Genis Mendoza AD, Narvaez LL, Humberto N: No association between COMT val158met polymorphism and suicidal behavior: meta-analysis and new data. BMC Psychiatry 2011, 11(151):11-151.

34. Jernej B, Stefulj J, Hranilovic D, Balija M, Skavic J, Kubat M: Intronic polymorphism of tryptophan hydroxylase and serotonin transporter: indication for combined effect in predisposition to suicide. J Neural Transm 2004, 111(6):733-738

35. Hong CJ, Tsai SJ, Wang YC: Association between tryptophan hydroxylase gene polymorphism (A218C) and schizophrenic disorders. Schizophr Res 2001, 49(1-2):59-63.

36. Rujescu D, Giegling I, Bondy B, Gietl A, Zill P, Moller HJ: Association of anger-related traits with SNPs in the TPH gene. Mol Psychiatry 2002, 7(9):1023-1029.

37. Souery D, Van Gestel S, Massat I, Blairy S, Adolfsson R, Blackwood D, Del-Favero J, Dikeos D, Jakovljevic M, Kaneva R, Lattuada E, Lerer B, Lilli R, Milanova V, Muir W, Nothen M, Oruc L, Papadimitriou G, Propping P, Schulze T, Serretti A, Shapira B, Smeraldi E, Stefanis C, Thomson M, Van Broeckhoven C, Mendlewicz J: Tryptophan hydroxylase polymorphism and suicidality in unipolar and bipolar affective disorders: a multicenter association study. Biol Psychiatry 2001, 49(5):405-409.

38. Nielsen DA, Virkkunen M, Lappalainen J, Eggert M, Brown GL, Long JC, Goldman D, Linnoila M: A tryptophan hydroxylase gene marker for suicidality and alcoholism. Arch Gen Psychiatry 1998, 55(7):593-602.

39. Turecki G, Zhu Z, Tzenova J, Lesage A, Seguin M, Tousignant M, Chawky N, Vanier C, Lipp O, Alda M, Joober R, Benkelfat C, Rouleau GA: TPH and suicida behavior: a study in suicide completers. Mol Psychiatry 2001, 6(1):98-102.

40. Zalsman G, Frisch A, King RA, Pauls DL, Grice DE, Gelernter J, Alsobrook J, Michaelovsky E, Apter A, Tyano S, Weizman A, Leckman JF: Case control and family-based studies of tryptophan hydroxylase gene A218C polymorphism and suicidality in adolescents. Am J Med Genet 2001, 105(5):451-457.

41. Buttenschon HN, Flint TJ, Foldager L, Qin P, Christoffersen S, Hansen NF, Kristensen IB, Mortensen PB, Borglum AD, Mors O: An association study of suicide and candidate genes in the serotonergic system. J Affect Disord 2013, 148(2-3):291-298.

42. Kunugi $H$, Ishida S, Kato T, Sakai T, Tatsumi M, Hirose T, Nanko S: No evidence for an association of polymorphisms of the tryptophan hydroxylase gene with affective disorders or attempted suicide among Japanese patients. Am J Psychiatry 1999, 156(5):774-776.

43. Ono H, Shirakawa O, Nishiguchi N, Nishimura A, Nushida H, Ueno Y, Maeda K: Tryptophan hydroxylase gene polymorphisms are not associated with suicide. Am J Med Genet 2000, 96(6):861-863.
44. Yoon HK, Kim YK: Association between serotonin-related gene polymorphisms and suicidal behavior in depressive patients. Prog Neuropsychopharmacol Biol Psychiatry 2008, 32(5):1293-1297.

45. Paik I, Toh K, Kim J, Lee C: TPH gene may be associated with suicidal behavior, but not with schizophrenia in the Korean population. Hum Hered 2000, 50(6):365-369.

46. Stefulj J, Kubat M, Balija M, Jernej B: TPH gene polymorphism and aging: indication of combined effect on the predisposition to violent suicide. Am J Med Genet B Neuropsychiatr Genet 2006, 5(2):139-141.

47. Abbar M, Courtet $P$, Bellivier F, Leboyer M, Boulenger JP, Castelhau D, Ferreira M, Lambercy C, Mouthon D, Paoloni-Giacobino A, Vessaz M, Malafosse A, Buresi $\mathrm{C}$ : Suicide attempts and the tryptophan hydroxylase gene. Mol Psychiatry 2001, 6(3):268-273.

48. Viana MM, De Marco LA, Boson WL, Romano-Silva MA, Correa H: Investigation of $\mathrm{A} 218 \mathrm{C}$ tryptophan hydroxylase polymorphism: association with familial suicide behavior and proband's suicide attempt characteristics. Genes Brain Behav 2006, 5(4):340-345.

49. Ohtani M, Shindo S, Yoshioka N: Polymorphisms of the tryptophan hydroxylase gene and serotonin $1 \mathrm{~A}$ receptor gene in suicide victims among Japanese. Tohoku J Exp Med 2004, 202(2):123-133.

50. Pooley EC, Houston K, Hawton K, Harrison PJ: Deliberate self-harm is associated with allelic variation in the tryptophan hydroxylase gene (TPH A779C), but not with polymorphisms in five other serotonergic genes. Psychol Med 2003, 33(5):775-783.

51. Rotondo A, Schuebel K, Bergen A, Aragon R, Virkkunen M, Linnoila M, Goldman D, Nielsen D: Identification of four variants in the tryptophan hydroxylase promoter and association to behavior. Mol Psychiatry 1999, 4(4):360-368.

52. Wilson ST, Stanley B, Brent DA, Oquendo MA, Huang YY, Mann JJ: The tryptophan hydroxylase-1 A218C polymorphism is associated with diagnosis, but not suicidal behavior, in borderline personality disorder. Am J Med Genet B Neuropsychiatr Genet 2009, 5(2):202-208.

53. Geijer T, Frisch A, Persson ML, Wasserman D, Rockah R, Michaelovsky E, Apter A, Jonsson EG, Nothen MM, Weizman A: Search for association between suicide attempt and serotonergic polymorphisms. Psychiatr Genet 2000, 10(1):19-26.

54. Du L, Faludi G, Palkovits M, Bakish D, Hrdina PD: Tryptophan hydroxylase gene $218 \mathrm{~A} / \mathrm{C}$ polymorphism is not associated with depressed suicide. Int J Neuropsychopharmacol 2000, 3(3):215-220.

55. Tsai SJ, Hong CJ, Wang YC: Tryptophan hydroxylase gene polymorphism (A218C) and suicidal behaviors. Neuroreport 1999, 10(18):3773-3775.

56. Liu X, Li H, Qin W, He G, Li D, Shen Y, Shen J, Gu N, Feng G, He L: Association of TPH1 with suicidal behaviour and psychiatric disorders in the Chinese population. J Med Genet 2006, 43(2):e4.

57. Stefulj J, Mokrovic G, Hranilovic D, Bordukalo-Niksic T, Bakula M, Kubat M, Jernej B: Functional promoter polymorphism of the neuronal isoform of tryptophan hydroxylase (Tph2) in suicide. Psychiatry Res 2011, 186(2-3):446-447.

58. Mouri K, Hishimoto A, Fukutake M, Shiroiwa K, Asano M, Nagasaki Y, Ueno Y, Shirakawa O, Nishiguchi N, Maeda K: TPH2 is not a susceptibility gene for suicide in Japanese population. Prog Neuropsychopharmacol Biol Psychiatry 2009, 33(8):1546-1550.

59. Must A, Tasa G, Lang A, Vasar E, Koks S, Maron E, Vali M: Variation in tryptophan hydroxylase-2 gene is not associated to male completed suicide in Estonian population. Neurosci Lett 2009, 453(2):112-114.

60. Zill P, Preuss UW, Koller G, Bondy B, Soyka M: SNP- and haplotype analysis of the tryptophan hydroxylase 2 gene in alcohol-dependent patients and alcohol-related suicide. Neuropsychopharmacology 2007, 32(8):1687-1694

61. Zhou Z, Roy A, Lipsky R, Kuchipudi K, Zhu G, Taubman J, Enoch MA Virkkunen M, Goldman D: Haplotype-based linkage of tryptophan hydroxylase 2 to suicide attempt, major depression, and cerebrospinal fluid 5-hydroxyindoleacetic acid in 4 populations. Arch Gen Psychiatry 2005, 62(10):1109-1118.

62. Bellivier F, Leboyer M, Courtet P, Buresi C, Beaufils B, Samolyk D, Allilaire JF, Feingold J, Mallet J, Malafosse A: Association between the tryptophan hydroxylase gene and manic-depressive illness. Arch Gen Psychiatry 1998, 55(1):33-37.

63. Kavvoura FK, loannidis JP: Methods for meta-analysis in genetic association studies: a review of their potential and pitfalls. Hum Genet 2008, 123(1):1-14. 
64. Angles MR, Ocana DB, Medellin BC, Tovilla-Zarate C: No association between the HTR1A gene and suicidal behavior: a meta-analysis. Rev Bras Psiquiatr 2012, 34(1):38-42.

65. Gonzalez-Castro TB, Tovilla-Zarate C, Juarez-Rojop I, Pool Garcia S,

Velazquez-Sanchez MP, Genis A, Nicolini H, Lopez Narvaez L: Association of the 5HTR2A gene with suicidal behavior: case-control study and updated meta-analysis. BMC Psychiatry 2013, 13(25):13-25.

66. Stang A: Critical evaluation of the Newcastle-Ottawa scale for the assessment of the quality of nonrandomized studies in meta-analyses. Eur J Epidemiol 2010, 25(9):603-605.

67. Mann JJ: The serotonergic system in mood disorders and suicidal behaviour. Philos Trans R Soc Lond B Biol Sci 2013, 368(1615):20120537.

68. Schild AH, Pietschnig J, Tran US, Voracek M: Genetic association studies between SNPs and suicidal behavior: a meta-analytical field synopsis. Prog Neuropsychopharmacol Biol Psychiatry 2013, 46:36-42.

doi:10.1186/1471-244X-14-196

Cite this article as: González-Castro et al:: Association of TPH- 1 and $\mathrm{TPH}-2$ gene polymorphisms with suicidal behavior: a systematic review and meta-analysis. BMC Psychiatry 2014 14:196.

\section{Submit your next manuscript to BioMed Central and take full advantage of:}

- Convenient online submission

- Thorough peer review

- No space constraints or color figure charges

- Immediate publication on acceptance

- Inclusion in PubMed, CAS, Scopus and Google Scholar

- Research which is freely available for redistribution 